\title{
Review
}

\section{Essential versus accessory aspects of cell death: recommendations of the NCCD 2015}

\begin{abstract}
L Galluzzi ${ }^{\star 1,1,2,3,126}$, JM Bravo-San Pedro ${ }^{1,2,4}$, I Vitale $^{5}$, SA Aaronson ${ }^{6}$, JM Abrams ${ }^{7}$, D Adam ${ }^{8}$, ES Alnemri ${ }^{9}$, L Altucci ${ }^{10}$, D Andrews ${ }^{11}$, M Annicchiarico-Petruzzelli ${ }^{12}$, EH Baehrecke ${ }^{13}$, NG Bazan ${ }^{14}$, MJ Bertrand ${ }^{15,16}, \mathrm{~K} \mathrm{Bianchi}^{17,18}$, MV Blagosklonny ${ }^{19}$, K Blomgren ${ }^{20}$, C Borner ${ }^{21}$, DE Bredesen ${ }^{22,23}$, C Brenner ${ }^{24,25,26}$, M Campanella ${ }^{27}$, E Candi ${ }^{28}$, F Cecconi ${ }^{29,30,31}$, FK Chan ${ }^{32}$, NS Chandel ${ }^{33}$, EH Cheng ${ }^{34}$, JE Chipuk ${ }^{6}$, JA Cidlowski ${ }^{35}$, A Ciechanover ${ }^{36}$, TM Dawson ${ }^{37,38}$, VL Dawson ${ }^{37,38}$, V De Laurenzi ${ }^{39}$, R De Maria ${ }^{5}$, K-M Debatin ${ }^{40}$, N Di Daniele ${ }^{41}$, VM Dixit ${ }^{42}$, BD Dynlacht ${ }^{43}$, WS El-Deiry ${ }^{44}$, GM Fimia ${ }^{45,46}$, RA Flavel ${ }^{47}$, S Fulda ${ }^{48}$, C Garrido ${ }^{49,50}$, M-L Gougeon ${ }^{51}$, DR Green ${ }^{52}$, H Gronemeyer ${ }^{53}$, G Hajnoczky ${ }^{54}$, JM Hardwick ${ }^{55}$, MO Hengartner ${ }^{56}$, H Ichijo $0^{57}$, B Joseph ${ }^{58}$, PJ Jost ${ }^{59}$, T Kaufmann ${ }^{60}$, O Kepp ${ }^{2,4,61}$, DJ Klionsky ${ }^{62}$, RA Knight ${ }^{63,64}$, S Kumar ${ }^{65,66}$, JJ Lemasters ${ }^{67}$, B Levine ${ }^{68,69}$, A Linkermann ${ }^{70}$, SA Lipton ${ }^{71,72,73,74}$, RA Lockshin ${ }^{75}$, C López-Otín ${ }^{76}$, E Lugli ${ }^{77}, \mathrm{~F}$ Madeo $^{78}$, W Malorni ${ }^{79,80}, \mathrm{~J}-\mathrm{C}$ Marine ${ }^{81,82}$, SJ Martin ${ }^{83}$, J-C Martinou ${ }^{84}$, JP Medema ${ }^{85}$, P Meier ${ }^{86}$, S Melino ${ }^{87}$, N Mizushima ${ }^{88}$, U Moll ${ }^{89}$, C Muñoz-Pinedo ${ }^{90}$, G Nuñez ${ }^{91}$, A Obers ${ }^{92}$, T Panaretakis ${ }^{58}$, JM Penninger ${ }^{93}$, ME Peter ${ }^{94}$, M Piacentini ${ }^{30,46}$, P Pinton ${ }^{95}$, JH Prehn ${ }^{96}$, H Puthalakath ${ }^{97}$, GA Rabinovich ${ }^{98}$, KS Ravichandran ${ }^{99}$, R Rizzuto ${ }^{100}$, CM Rodrigues ${ }^{101}$, DC Rubinsztein ${ }^{102}$, T Rudel ${ }^{103}$, Y Shi ${ }^{104}, \mathrm{H}-\mathrm{U}$ Simon ${ }^{105}$, BR Stockwell ${ }^{69,106}$, G Szabadkai $^{100,107}$, SW Tait $^{108,109}$, HL Tang ${ }^{55}$, N Tavernarakis ${ }^{110,111}$, Y Tsujimoto ${ }^{112}$, T Vanden Berghe ${ }^{15,16}$, P Vandenabeele ${ }^{15,16,113}$, A Villunger ${ }^{114}$, EF Wagner ${ }^{115}$ ', H Walczak ${ }^{116}$, E White ${ }^{117}$, WG Wood ${ }^{118,119}$, J Yuan ${ }^{120}$, Z Zakeri $^{121,122}$, B Zhivotovsky ${ }^{123,124}$, G Melino ${ }^{28,64}$ and G Kroemer ${ }^{*, 2,3,4,61,125,126}$
\end{abstract}

${ }_{1}^{1}$ Gustave Roussy Cancer Center, Villejuif, France; ${ }^{2}$ Equipe 11 labellisée par la Ligue Nationale contre le Cancer, Centre de Recherche des Cordeliers, Paris, France; ${ }^{3}$ Université Paris Descartes/Paris V, Sorbonne Paris Cité, Paris, France; ${ }^{4}$ INSERM, U1138, Gustave Roussy, Paris, France; ${ }^{5}$ Regina Elena National Cancer Institute, Rome, Italy; ${ }^{6}$ Department of Oncological Sciences, The Tisch Cancer Institute, Ichan School of Medicine at Mount Sinai, New York, NY, USA; ${ }^{7}$ Department of Cell Biology, UT Southwestern Medical Center, Dallas, TX, USA; ${ }^{8}$ Institute of Immunology, Christian-Albrechts University, Kiel, Germany; ${ }^{9}$ Department of Biochemistry and Molecular Biology, Thomas Jefferson University, Philadelphia, PA, USA; ${ }^{10}$ Dipartimento di Biochimica, Biofisica e Patologia Generale, Seconda Università degli Studi di Napoli, Napoli, Italy; ${ }^{11}$ Department of Biochemistry and Medical Biophysics, University of Toronto, Toronto, ON, Canada; ${ }^{12}$ Biochemistry Laboratory, Istituto Dermopatico dell'Immacolata - Istituto Ricovero Cura Carattere Scientifico (IDI-IRCCS), Rome, Italy; ${ }^{13}$ Department of Cancer Biology, University of Massachusetts Medical School, Worcester, MA, USA; ${ }^{14}$ Neuroscience Center of Excellence, School of Medicine, New Orleans, LA, USA; ${ }^{15}$ VIB Inflammation Research Center, Ghent, Belgium; ${ }^{16}$ Department of Biomedical Molecular Biology, Ghent University, Ghent, Belgium; ${ }^{17}$ Barts Cancer Institute, Cancer Research UK Centre of Excellence, London, UK; ${ }^{18}$ Queen Mary University of London, John Vane Science Centre, London, UK; ${ }^{19}$ Department of Cell Stress Biology, Roswell Park Cancer Institute, Buffalo, NY, USA; ${ }^{20}$ Karolinska University Hospital, Karolinska Institute, Stockholm, Sweden; ${ }^{21}$ Institute of Molecular Medicine and Spemann Graduate School of Biology and Medicine, Albert-Ludwigs University, Freiburg, Germany; ${ }^{22}$ Buck Institute for Research on Aging, Novato, CA, USA; ${ }^{23}$ Department of Neurology, University of California, San Francisco (UCSF), San Francisco, CA, USA; ${ }^{24}$ INSERM, UMRS769, Châtenay Malabry, France; ${ }^{25}$ LabEx LERMIT, Châtenay Malabry, France; ${ }^{26}$ Université Paris Sud/Paris XI, Orsay, France; ${ }^{27}$ Department of Comparative Biomedical Sciences and Consortium for Mitochondrial Research, University College London (UCL), London, UK; ${ }^{28}$ Department of Experimental Medicine and Surgery, University of Rome Tor Vergata, Rome, Italy; ${ }^{29}$ Laboratory of Molecular Neuroembryology, IRCCS Fondazione Santa Lucia, Rome, Italy; ${ }^{30}$ Department of Biology, University of Rome Tor Vergata; Rome, Italy; ${ }^{31}$ Unit of Cell Stress and Survival, Danish Cancer Society Research Center, Copenhagen, Denmark; ${ }^{32}$ Department of Pathology, University of Massachusetts Medical School, Worcester, MA, USA; ${ }^{33}$ Department of Medicine, Feinberg School of Medicine, Northwestern University, Chicago, IL, USA; ${ }^{34}$ Human Oncology and Pathogenesis Program and Department of Pathology, Memorial Sloan Kettering Cancer Center (MSKCC), New York, NY, USA; ${ }^{35}$ Laboratory of Signal Transduction, National Institute of Environmental Health Sciences (NIEHS), National Institute of Health $(\mathrm{NIH})$, North Carolina, NC, USA; ${ }^{36}$ Tumor and Vascular Biology Research Center, The Rappaport Faculty of Medicine and Research Institute, Technion Israel Institute of Technology, Haifa, Israel; ${ }^{37}$ Neuroregeneration and Stem Cell Programs, Institute for Cell Engineering (ICE), Departments of Neurology, Pharmacology and Molecular Sciences, Solomon H Snyder Department of Neuroscience, Johns Hopkins University School of Medicine, Baltimore, MD, USA; ${ }^{38}$ Adrienne Helis Malvin Medical Research Foundation, New Orleans, LA, USA; ${ }^{39}$ Department of Experimental and Clinical Sciences, Gabriele d'Annunzio University, Chieti, Italy; ${ }^{40}$ Department of Pediatrics and Adolescent Medicine, Ulm University Medical Center, Ulm, Germany; ${ }^{41}$ Department of Systems Medicine, University of Rome Tor Vergata, Rome, Italy; ${ }^{42}$ Department of Physiological Chemistry, Genentech, South San Francisco, CA, USA; ${ }^{43}$ Department of Pathology and Cancer Institute, Smilow Research Center, New York University School of Medicine, New York, NY, USA; ${ }^{44}$ Laboratory of Translational Oncology and Experimental Cancer Therapeutics, Department of Medicine (Hematology/Oncology), Penn State Hershey Cancer Institute, Penn State College of Medicine, Hershey, PA, USA; ${ }^{45}$ Department of Biological and Environmental Sciences and Technologies (DiSTeBA), University of Salento, Lecce, Italy; ${ }^{46}$ Department of Epidemiology and Preclinical Research, National Institute for Infectious Diseases Lazzaro Spallanzani, Istituto Ricovero Cura Carattere Scientifico (IRCCS), Rome, Italy; ${ }^{47}$ Department of Immunobiology, Yale School of Medicine, New Haven, CT, USA; ${ }^{48}$ Institute for Experimental Cancer Research in Pediatrics, Goethe University, Frankfurt, Germany; ${ }^{49}$ INSERM, U866, Dijon, France; ${ }^{50}$ Faculty of Medicine, University of Burgundy, Dijon, France and ${ }^{51}$ Antiviral Immunity, Biotherapy and Vaccine Unit, Infection and Epidemiology Department, Institut Pasteur, Paris, France

Abbreviations: ACD, accidental cell death; APAF1, apoptotic peptidase-activating factor 1; BAX, BCL2-associated X protein; BAK1, BCL2-antagonist/killer 1; BCL2, B-cell CLL/lymphoma 2; BID, BH3-interacting domain death agonist; BIRC, baculoviral IAP repeat containing; CASP3, caspase-3; CASP8, caspase-8; CASP9, caspase9; CYPD, cyclophilin D; DAMP, damage-associated molecular pattern; FADD, Fas (TNFRSF6)-associated via death domain; GPX4, glutathione peroxidase 4; MLKL, mixed lineage kinase domain-like; MOMP, mitochondrial outer membrane permeabilization; MPT, mitochondrial permeability transition; NCCD, Nomenclature Committee on Cell Death; Nec-1, necrostatin 1; PARP1, poly(ADP-ribose) polymerase 1; PCD, programmed cell death; PPIF, peptidylprolyl isomerase F; PTPC, permeability transition pore complex; Q-VD-OPh, (3S)-5-(2,6-difluorophenoxy)-3-[(2S)-3-methyl-1-oxo-2-[(2-quinolinylcarbonyl)amino]butyl]amino]-4-oxo-pentanoic acid hydrate; RCD, regulated cell death; RIPK1, receptor-interacting protein kinase 1; RIPK3, receptor-interacting protein kinase 3; SMAC, second mitochondria-derived activator of caspases; TAK1, TGF $\beta$-activated kinase 1; TLR, Toll-like receptor; TNFR1, tumor necrosis factor receptor 1; XIAP, X-linked inhibitor of apoptosis; Z-VADfmk, $\mathrm{N}$-benzyloxycarbonyl-Val-Ala-Asp(O-Me) fluoromethylketone

${ }^{126}$ Share senior co-authorship.

Received 23.7.14; accepted 30.7.14; Edited by A Stephanou; published online 19.9.14

Cell Death and Differentiation 
Cells exposed to extreme physicochemical or mechanical stimuli die in an uncontrollable manner, as a result of their immediate structural breakdown. Such an unavoidable variant of cellular demise is generally referred to as 'accidental cell death' (ACD). In most settings, however, cell death is initiated by a genetically encoded apparatus, correlating with the fact that its course can be altered by pharmacologic or genetic interventions. 'Regulated cell death' (RCD) can occur as part of physiologic programs or can be activated once adaptive responses to perturbations of the extracellular or intracellular microenvironment fail. The biochemical phenomena that accompany RCD may be harnessed to classify it into a few subtypes, which often (but not always) exhibit stereotyped morphologic features. Nonetheless, efficiently inhibiting the processes that are commonly thought to cause RCD, such as the activation of executioner caspases in the course of apoptosis, does not exert true cytoprotective effects in the mammalian system, but simply alters the kinetics of cellular demise as it shifts its morphologic and biochemical correlates. Conversely, bona fide cytoprotection can be achieved by inhibiting the transduction of lethal signals in the early phases of the process, when adaptive responses are still operational. Thus, the mechanisms that truly execute RCD may be less understood, less inhibitable and perhaps more homogeneous than previously thought. Here, the Nomenclature Committee on Cell Death formulates a set of recommendations to help scientists and researchers to discriminate between essential and accessory aspects of cell death.

Cell Death and Differentiation (2015) 22, 58-73; doi:10.1038/cdd.2014.137; published online 19 September 2014

\begin{abstract}
${ }^{52}$ Department of Immunology, St Jude's Children's Research Hospital, Memphis, TN, USA; ${ }^{53}$ Department of Functional Genomics and Cancer, Institut de Génétique et de Biologie Moléculaire et Cellulaire (IGBMC), Illkirch, France; ${ }^{54}$ Department of Pathology, Anatomy and Cell Biology, Thomas Jefferson University, Philadelphia, PA, USA; ${ }^{55}$ W Harry Feinstone Department of Molecular Microbiology and Immunology, Johns Hopkins University, Baltimore, MD, USA; ${ }^{56}$ Institute of Molecular Life Sciences, University of Zurich, Zurich, Switzerland; ${ }^{57}$ Laboratory of Cell Signaling, Graduate School of Pharmaceutical Sciences, University of Tokyo, Tokyo, Japan; ${ }^{58}$ Department of Oncology-Pathology, Cancer Centrum Karolinska (CCK), Karolinska Institute, Stockholm, Sweden; ${ }^{59}$ Medical Department for Hematology, Technical University of Munich, Munich, Germany; ${ }^{60}$ Institute of Pharmacology, Medical Faculty, University of Bern, Bern, Switzerland; ${ }^{61}$ Metabolomics and Cell Biology Platforms, Gustave Roussy Cancer Center, Villejuif, France; ${ }^{62}$ Life Sciences Institute, University of Michigan, Ann Arbor, MI, USA; ${ }^{63}$ Medical Molecular Biology Unit, Institute of Child Health, University College London (UCL), London, UK; ${ }^{64}$ Medical Research Council Toxicology Unit, Leicester, UK; ${ }^{65}$ Centre for Cancer Biology, University of South Australia, Adelaide, SA, Australia; ${ }^{66}$ School of Medicine and School of Molecular and Biomedical Science, University of Adelaide, Adelaide, SA, Australia; ${ }^{67}$ Departments of Drug Discovery and Biomedical Sciences and Biochemistry and Molecular Biology, Medical University of South Carolina, Charleston, SC, USA; ${ }^{68}$ Center for Autophagy Research, University of Texas, Southwestern Medical Center, Dallas, TX, USA; ${ }^{69}$ Howard Hughes Medical Institute (HHMI), Chevy Chase, MD, USA; ${ }^{70}$ Division of Nephrology and Hypertension, Christian-Albrechts University, Kiel, Germany; ${ }^{71}$ The Scripps Research Institute, La Jolla, CA, USA; ${ }^{72}$ SanfordBurnham Center for Neuroscience, Aging, and Stem Cell Research, La Jolla, CA, USA; ${ }^{73}$ Salk Institute for Biological Studies, La Jolla, CA, USA; ${ }^{74}$ University of California, San Diego (UCSD), San Diego, CA, USA; ${ }^{75}$ Department of Biological Sciences, St. John's University, Queens, NY, USA; ${ }^{76}$ Department of Biochemistry and Molecular Biology, Faculty of Medecine, Instituto Universitario de Oncología (IUOPA), University of Oviedo, Oviedo, Spain; ${ }^{77}$ Unit of Clinical and Experimental Immunology, Humanitas Clinical and Research Center, Milan, Italy; ${ }^{78}$ Institute of Molecular Biosciences, University of Graz, Graz, Austria; ${ }^{79}$ Department of Therapeutic Research and Medicine Evaluation, Istituto Superiore di Sanita (ISS), Roma, Italy; ${ }^{80}$ San Raffaele Institute, Sulmona, Italy; ${ }^{81}$ Laboratory for Molecular Cancer Biology, Center for the Biology of Disease, Leuven, Belgium; ${ }^{82}$ Laboratory for Molecular Cancer Biology, Center of Human Genetics, Leuven, Belgium; ${ }^{83}$ Department of Genetics, The Smurfit Institute, Trinity College, Dublin, Ireland; ${ }^{84}$ Department of Cell Biology, University of Geneva, Geneva, Switzerland; ${ }^{85}$ Laboratory for Experiments Oncology and Radiobiology (LEXOR), Academic Medical Center (AMC), Amsterdam, The Netherlands; ${ }^{86}$ Institute of Cancer Research, The Breakthrough Toby Robins Breast Cancer Research Centre, London, UK; ${ }^{87}$ Department of Chemical Sciences and Technologies, University of Rome Tor Vergata, Rome, Italy; ${ }^{88} \mathrm{Graduate}$ School and Faculty of Medicine, University of Tokyo, Tokyo, Japan; ${ }^{89}$ Department of Pathology, Stony Brook University, Stony Brook, NY, USA; ${ }^{90}$ Cell Death Regulation Group, Bellvitge Biomedical Research Institute (IDIBELL), Barcelona, Spain; ${ }^{91}$ Department of Pathology and Comprehensive Cancer Center, University of Michigan Medical School, Ann Arbor, MI, USA; ${ }^{92}$ Department of Immunology, University of Washington, Seattle, WA, USA; ${ }^{93}$ Institute of Molecular Biotechnology of the Austrian Academy of Sciences, Vienna, Austria; ${ }^{94}$ Department of Hematology/Oncology, Feinberg School of Medicine, Northwestern University, Chicago, IL, USA; ${ }^{95}$ Department of Morphology, Surgery and Experimental Medicine, Section of Pathology, Oncology and Experimental Biology and LTTA Center, University of Ferrara, Ferrara, Italy; ${ }^{96}$ Department of Physiology and Medical Physics, Royal College of Surgeons, Dublin, Ireland; ${ }^{97}$ Department of Biochemistry, La Trobe Institute of Molecular Science, La Trobe University, Melbourne, Australia; ${ }^{98}$ Laboratory of Immunopathology, Instituto de Biología y Medicina Experimental (IBYME), Consejo Nacional de Investigaciones Científicas y Técnicas (CONICET), Buenos Aires, Argentina; ${ }^{99}$ Department of Microbiology, Immunology and Cancer Biology, University of Virginia, Charlottesville, VA, USA; ${ }^{100}$ Department Biomedical Sciences, University of Padova, Padova, Italy; ${ }^{101}$ Research Institute for Medicines, Faculty of Pharmacy, University of Lisbon, Lisbon, Portugal; ${ }^{102}$ Department of Medical Genetics, Cambridge Institute for Medical Research, University of Cambridge School of Clinical Medicine, Cambridge, UK; ${ }^{103}$ Department of Microbiology, University of Würzburg; Würzburg, Germany; ${ }^{104}$ Soochow Institute for Translational Medicine, Soochow University, Suzhou, China; ${ }^{105}$ Institute of Pharmacology, University of Bern, Bern, Switzerland; ${ }^{106}$ Departments of Biological Sciences and Chemistry, Columbia University, New York, NY, USA; ${ }^{107}$ Department of Cell and Developmental Biology and Consortium for Mitochondrial Research, University College London (UCL), London, UK; ${ }^{108}$ Cancer Research UK Beatson Institute, Glasgow, UK; ${ }^{109}$ Institute of Cancer Sciences, University of Glasgow, Glasgow, UK; ${ }^{11}$ Institute of Molecular Biology and Biotechnology, Foundation for Research and Technology-Hellas, Heraklion, Crete, Greece; ${ }^{111}$ Department of Basic Sciences, Faculty of Medicine, University of Crete, Heraklion, Crete, Greece; ${ }^{112}$ Osaka Medical Center for Cancer and Cardiovascular Diseases, Osaka, Japan; ${ }^{113}$ Methusalem Program, Ghent University, Ghent, Belgium; ${ }^{114}$ Division of Developmental Immunology, Biocenter, Medical University Innsbruck, Innsbruck, Austria; ${ }^{115}$ Cancer Cell Biology Program, Spanish National Cancer Research Centre (CNIO), Madrid, Spain; ${ }^{116}$ Centre for Cell Death, Cancer and Inflammation (CCCI), UCL Cancer Institute, University College London (UCL), London, UK; ${ }^{117}$ Rutgers Cancer Institute of New Jersey, New Brunswick, NJ, USA: ${ }^{118}$ Department of Pharmacology, University of Minnesota School of Medicine, Minneapolis, MN, USA; ${ }^{119}$ Geriatric Research, Education and Clinical Center, VA Medical Center, Minneapolis, MN, USA; ${ }^{120}$ Department of Cell Biology, Harvard Medical School, Boston, MA, USA; ${ }^{121}$ Department of Biology, Queens College, Queens, NY, USA; ${ }^{122}$ Graduate Center, City University of New York (CUNY), Queens, NY, USA; ${ }^{123}$ Division of Toxicology, Institute of Environmental Medicine, Karolinska Institute, Stockholm, Sweden; ${ }^{124}$ Faculty of Fundamental Medicine, Lomonosov Moscow State University, Moscow, Russia; ${ }^{125}$ Pôle de Biologie, Hôpital Européen Georges Pompidou, AP-HP, Paris, France.

*Corresponding authors: L Galluzzi or G Kroemer, Equipe 11 - 'Apoptose, cancer et immunité', Centre de Recherche des Cordeliers, 15 rue de l'École de Médecine, 75006 Paris, France. Tel: +33 144277661 or +33 14427 7667; Fax: +33 14427 7674; E-mail: deadoc@ vodafone.it or kroemer@orange.fr
\end{abstract}


Defining life and death is more problematic than one would guess. In 1838, the work of several scientists including Matthias Jakob Schleiden, Theodor Schwann and Rudolf Carl Virchow culminated in the so-called 'cell theory', postulating that: (1) all living organisms are composed of one or more cells; (2) the cell is the basic unit of life; and (3) all cells arise from pre-existing, living cells. ${ }^{1}$ Only a few decades later (in 1885), Walter Flemming described for the first time some of the morphologic features that have been largely (but often inappropriately) used to define apoptosis throughout the past four decades. ${ }^{2-4}$

A corollary of the cell theory is that viruses do not constitute bona fide living organisms. ${ }^{5}$ However, the discovery that the giant Acanthamoeba polyphaga mimivirus can itself be infected by other viral species has casted doubts on this point. ${ }^{6-8}$ Thus, the features that underlie the distinction between a living and an inert entity remain a matter of debate. Along similar lines, defining the transition between an organism's life and death is complex, even when the organism under consideration is the basic unit of life, a cell. From a conceptual standpoint, cell death can obviously be defined as the permanent degeneration of vital cellular functions. Pragmatically speaking, however, the precise boundary between a reversible alteration in homeostasis and an irreversible loss of cellular activities appears to be virtually impossible to identify. To circumvent this issue, the Nomenclature Committee on Cell Death (NCCD) previously proposed three criteria for the identification of dead cells: (1) the permanent loss of the barrier function of the plasma membrane; (2) the breakdown of cells into discrete fragments, which are commonly referred to as apoptotic bodies; or (3) the engulfment of cells by professional phagocytes or other cells endowed with phagocytic activity. ${ }^{9-11}$

However, the fact that a cell is engulfed by another via phagocytosis does not imply that the cell-containing phagosome fuses with a lysosome and that the phagosomal cargo is degraded by lysosomal hydrolases. ${ }^{12-14}$ Indeed, it has been reported that engulfed cells can be released from phagosomes as they preserve their viability, at least under some circumstances. ${ }^{15}$ Thus, the NCCD recommends here to consider as dead only cells that either exhibit irreversible plasma membrane permeabilization or have undergone complete fragmentation. A compendium of techniques that can be used to quantify these two markers of end-stage cell death in vitro and in vivo goes beyond the scope of this review and can be found in several recent articles. ${ }^{16-25}$

Importantly, cell death instances can be operationally classified into two broad, mutually exclusive categories: 'accidental' and 'regulated'. Accidental cell death (ACD) is caused by severe insults, including physical (e.g., elevated temperatures or high pressures), chemical (e.g., potent detergents or extreme variations in $\mathrm{pH}$ ) and mechanical (e.g., shearing) stimuli, is virtually immediate and is insensitive to pharmacologic or genetic interventions of any kind. The NCCD thinks that this reflects the structural disassembly of cells exposed to very harsh physicochemical conditions, which does not involve a specific molecular machinery. Although ACD can occur in vivo, for instance as a result of burns or traumatic injuries, it cannot be prevented or modulated and hence does not constitute a direct target for therapeutic interventions. ${ }^{23,26-28}$ Nonetheless, cells exposed to extreme physicochemical or mechanical insults die while releasing elevated amounts of damage-associated molecular patterns (DAMPs), that is, endogenous molecules with immunomodulatory (and sometimes cytotoxic) activity. Some DAMPs can indeed propagate an unwarranted cytotoxic response (directly or upon the involvement of innate immune effectors) that promotes the demise of local cells surviving the primary insult. ${ }^{16,19,29-31}$ Intercepting DAMPs or blocking DAMP-ignited signaling pathways may mediate beneficial effects in a wide array of diseases involving accidental (as well as regulated) instances of cell death. ${ }^{19,32}$

At odds with its accidental counterpart, regulated cell death (RCD) involves a genetically encoded molecular machinery. ${ }^{9,33}$ Thus, the course of RCD can be altered by means of pharmacologic and/or genetic interventions targeting the key components of such a machinery. Moreover, RCD often occurs in a relatively delayed manner and is initiated in the context of adaptive responses that (unsuccessfully) attempt to restore cellular homeostasis. ${ }^{34-38}$ Depending on the initiating stimulus, such responses can preferentially involve an organelle, such as the reticular unfolded protein response, or operate at a cell-wide level, such as macroautophagy (hereafter referred to as autophagy)..$^{39-44}$ Thus, while ACD is completely unpreventable, RCD can be modulated (at least to some extent, see below) not only by inhibiting the transduction of lethal signals but also by improving the capacity of cells to mount adaptive responses to stress. ${ }^{45-50}$ Importantly, RCD occurs not only as a consequence of microenvironmental perturbations but also in the context of (post-)embryonic development, tissue homeostasis and immune responses. ${ }^{51-54}$ Such completely physiologic instances of RCD are generally referred to as 'programmed cell death' (PCD) (Figure 1). 9,33

For the purpose of this discussion, it is useful to keep in mind the distinction that is currently made between the initiation of RCD and its execution. The term execution is generally used to indicate the ensemble of biochemical processes that truly cause the cellular demise. Conversely, initiation is commonly used to refer to the signal transduction events that activate executioner mechanisms. Thus, the activation of caspase-8 (CASP8) in the course of FAS ligand (FASL)-triggered apoptosis is widely considered as an initiator mechanism, whereas the consequent activation of caspase-3 (CASP3) is categorized as an executioner mechanism (see below). ${ }^{51,55-57}$

Here, the NCCD formulates a set of recommendations to discriminate between essential and accessory aspects of $R C D$, that is, between those that etiologically mediate its occurrence and those that change its kinetics or morphologic and biochemical manifestations.

\section{Morphologic Aspects of Cell Death}

The early classifications of cell death were purely morphologic, owing to obvious technical limitations. ${ }^{18,20}$ In 1964, the American biologist Richard A Lockshin was the first to thoroughly describe the demise of intersegmental muscles in developing silk moths, a seminal contribution to the modern understanding of PCD. ${ }^{58}$ A few years later, in 1972, the Australian pathologist John F Kerr together with his Scottish 


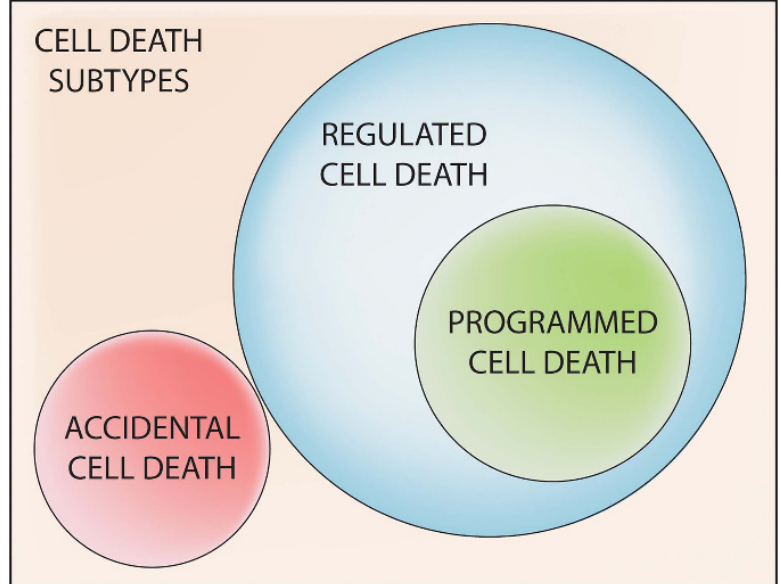

Figure 1 Types of cell death. Cells exposed to extreme physical, chemical or mechanical stimuli succumb in a completely uncontrollable manner, reflecting the immediate loss of structural integrity. We refer to such instances of cellular demise with the term 'accidental cell death' (ACD). Alternatively, cell death can be initiated by a genetically encoded machinery. The course of such 'regulated cell death' (RCD) variants can be influenced, at least to some extent, by specific pharmacologic or genetic interventions. The term 'programmed cell death' (PCD) is used to indicate RCD instances that occur as part of a developmental program or to preserve physiologic adult tissue homeostasis

colleagues Andrew H Wyllie and Alastair R Currie coined the

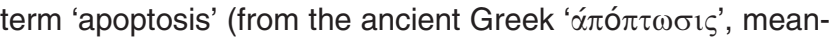
ing 'falling off') to indicate a morphologically stereotyped form of cellular demise characterized by cytoplasmic shrinkage, chromatin condensation initiating at the nuclear membrane (marginalization) and then involving the whole nucleus (pyknosis), nuclear fragmentation (karyorrhexis), minimal alterations of other organelles and a peculiar 'boiling-like' process (blebbing) culminating in the formation of a few discrete corpses that initially retain plasma membrane integrity (apoptotic bodies). ${ }^{10,11,59}$ Soon thereafter, the first 'formal' classification of cell death differentiated between: (1) type I cell death (apoptosis), manifesting with the morphologic features described above; (2) type II cell death (autophagy), featuring an extensive vacuolization of the cytoplasm; and (3) type III cell death (necrosis), exhibiting neither apoptotic nor autophagic characteristics. ${ }^{3,60}$ Such a 'visual catalog' has dominated the field of cell death research for decades. Nonetheless, the NCCD views it as an oversimplification and considers it rather misleading, for several reasons.

First, when this classification was formulated, necrosis (as defined by morphologic features) was considered as a strict equivalent of ACD, whereas apoptosis (as defined by morphologic features) was viewed as the sole programmed subroutine of cell death. ${ }^{11}$ Along similar lines, apoptosis was misconceived as an immunologically silent, if not tolerogenic, cell death modality. ${ }^{61,62}$ It is now clear that PCD does not always manifest with an apoptotic morphotype and does not necessarily fail to induce inflammatory or immune responses. For instance, the degradation of Drosophila melanogaster salivary glands and larval midgut relies on PCD manifesting with a type II morphology, ${ }^{63-70}$ whereas the remodeling of bones at the growth plates is associated with type III-like features. ${ }^{71}$ Moreover, specific inducers are capable of promoting a variant of RCD that displays an apoptotic morphotype, yet is capable of activating adaptive immune responses. ${ }^{72,73}$ These observations indicate that morphologic and functional aspects of cell death are not necessarily linked to each other.

Second, the negative morphologic definition of necrosis as a cell death modality that fails to exhibit apoptotic or autophagic features has been reconsidered. ${ }^{22,74}$ Indeed, necrosis can manifest with a stereotyped panel of features, including a generalized swelling of the cytoplasm, which acquires a translucent aspect, and organelles (oncosis), as well as a peculiar alteration of chromatin (condensation into small and irregular patches) and the nuclear membrane (dilatation). ${ }^{74}$ The evolution of the morphologic characterization of necrosis reflects the relatively recent discovery that $\mathrm{RCD}$ can also manifest with a necrotic aspect (see below).

Third, the use of the term 'autophagic cell death' has been a matter of intense debate. ${ }^{75}$ Such an expression was coined based on morphologic considerations (i.e., the appearance of autophagic vacuoles in the course of type II cell death) only, but it soon became misused to imply that the molecular machinery of autophagy would actively contribute to the cellular demise. ${ }^{75}$ The NCCD strongly recommends the use of the expression 'autophagic cell death' from a functional perspective only, that is, to indicate a cell death subroutine that is limited or delayed by the pharmacologic or genetic inhibition of the autophagic machinery (see below). ${ }^{9,76}$

Fourth, many instances of RCD present both apoptotic and necrotic traits. ${ }^{10}$ Moreover, several pharmacologic agents and genetic interventions designed to inhibit the execution of cell death often fail to do so when administered in a therapeutic (as opposed to prophylactic) ${ }^{77}$ manner, at least in the mammalian system, yet efficiently change its morphology. ${ }^{78-91}$ This applies to $\mathrm{N}$-benzyloxycarbonyl-Val-Ala-Asp(O-Me) fluoromethylketone (Z-VAD-fmk) and (3S)-5-(2,6-difluorophenoxy)-3-[[(2S)-3methyl-1-oxo-2-[(2-quinolinylcarbonyl)amino]butyl]amino]-4oxo-pentanoic acid hydrate (Q-VD-OPh), two broad-spectrum caspase inhibitors that have been widely investigated in the late 1990 s as a means to mediate clinically relevant cytoprotection. ${ }^{92-95}$ Z-VAD-fmk and Q-VD-OPh prevent the appearance of several morphologic markers of apoptosis, including nuclear pyknosis and blebbing (which rely on caspases), ${ }^{96,97}$ yet fail to limit stimulus-dependent cell death if administered in therapeutic settings (i.e., after the cell death inducer). ${ }^{85,98-100}$ Thus, caspase inhibition most often results in a shift from an overtly apoptotic to a mixed or necrotic cell death morphology. ${ }^{81,91}$ Conversely, both necrostatin 1 (Nec1), a highly specific small inhibitor of the enzymatic activity of receptor-interacting protein kinase 1 (RIPK1), and geldanamycin, which targets heat-shock protein $90 \mathrm{kDa}$ alpha (cytosolic), class A member 1 (HSP90AA1), have been demonstrated to shift the necrotic morphotype of RCD induced by tumor necrosis factor (ligand) superfamily, member 10 (TNFSF10, best known as TNF-related apoptosis-inducing ligand, TRAIL) at slightly acidic $\mathrm{pH}$ to an apoptotic one. ${ }^{101} \mathrm{~A}$ similar morphologic shift has been observed in cells succumbing to tumor necrosis factor receptor superfamily, member 1A (TNFRSF1A, best known as tumor necrosis factor receptor 1, TNFR1) ligation in the presence of geldanamy$\operatorname{cin}^{102}$ and in the absence of RIPK1 or one of its downstream targets, that is, receptor-interacting protein kinase 3 (RIPK3) 
and mixed lineage kinase domain-like (MLKL). ${ }^{103,104}$ Also, cells exposed to DNA-alkylating agents in the presence of poly(ADP-ribose) polymerase 1 (PARP1) inhibitors die while manifesting an apoptotic, rather than a necrotic, morphology. ${ }^{105,106}$ Conversely, the introduction of a non-cleavable PARP1 variant appears to convert the apoptotic phenotype of cells succumbing to FAS ligation into a necrotic one. ${ }^{107}$ Possibly, this reflects the ability of PARP1, an $\mathrm{NAD}^{+}$dependent enzyme initially characterized for its role in DNA repair and the DNA damage response, ${ }^{108,109}$ to provoke an abrupt decline in intracellular ATP levels (secondary to NAD ${ }^{+}$ depletion), hence blocking various morphologic manifestations of apoptosis. ${ }^{110-115}$ Such a morphologic shift, however, does not appear to stem from the inhibition of caspases, because neither the catalytic functions nor the activation of these proteases require ATP (which should not be confounded with deoxy-ATP, see below). ${ }^{116-119}$

In summary, the morphologic manifestations of cell death can easily be altered in the absence of bona fide cytoprotection, casting doubts on the actual value of morphology-based classifications of cell death. ${ }^{9}$

\section{Biochemical Manifestations of Cell Death}

In 2012, the NCCD proposed to abandon the morphologic catalog of cell death instances in favor of a new classification based on quantifiable biochemical parameters. ${ }^{9}$ In substitution, the NCCD identified the main molecular events associated with specific cell death subroutines as well as the pharmacologic and/or genetic interventions that may be used to discriminate between various instances of cell death in experimental settings, in vitro and in vivo. ${ }^{9}$

Since then, our comprehension of specific RCD modalities has progressed significantly. Thus, while no paradigm-breaking discoveries have been made on the regulation and execution of caspase-dependent RCD instances (which most often display an apoptotic morphology), profound insights have been obtained into the mechanisms underlying cases of RCD that do not depend on caspases and generally manifest with necrotic features. ${ }^{33,74,120,121}$ This notion began to emerge in the late 1980 s, $^{122}$ but became widely accepted only two decades later, owing to the milestone discoveries of Peter Vandenabeele, ${ }^{123-127}$ Jurg Tschopp ${ }^{128}$ and Junying Yuan, ${ }^{129-131}$ and to the characterization of the key role played by peptidylprolyl isomerase F (PPIF, best known as cyclophilin D, CYPD) in necrotic instances of RCD. ${ }^{132-135}$ The identification of a genetically encoded machinery that promotes RCD with necrotic features generated an intense wave of investigation that has not yet come to an end. ${ }^{33,74,120,121}$

From a biochemical standpoint, apoptosis is defined as a caspase-dependent variant of RCD.9,51 Other events commonly associated with apoptosis, such as the exposure of phosphatidylserine on the outer leaflet of the plasma membrane, are indeed less universal and more contextdependent ${ }^{136-139}$ than previously thought. ${ }^{140}$ Apoptosis can be initiated by intracellular (intrinsic) or extracellular (extrinsic) stimuli. Intrinsic apoptosis critically relies on mitochondrial outer membrane permeabilization (MOMP), a process that results in the holocytochrome $c$ (CYTC)-, deoxy-ATP- and apoptotic peptidase-activating factor 1 (APAF1)-dependent activation of caspase-9 (CASP9) and CASP3. ${ }^{117,141-144}$ MOMP obligatorily requires either of two $\mathrm{Bcl}-2$ family members, namely, B-cell CLL/lymphoma 2 (BCL2)-associated X protein (BAX) and BCL2-antagonist/killer 1 (BAK1), whose pore-forming activity is inhibited (both directly and via indirect circuitries) by other components of the family, including BCL2 itself, BCL2-like 1 (BCL2L1, best known as $\mathrm{BCL}-\mathrm{X}_{\mathrm{L}}$ ) and myeloid cell leukemia 1 (MCL1). ${ }^{48,145-148}$ Importantly, the physical and functional interactions between pro- and antiapoptotic multidomain BCL2-like proteins are under the control of small components of the family known as $\mathrm{BH}$ 3-only proteins, including (but not limited to) BCL2 binding component 3 (BBC3, best known as PUMA), BCL2-like 11 (BCL2L11, best known as BIM) and BH3-interacting domain death agonist (BID). ${ }^{149-151}$

Extrinsic apoptosis proceeds along with the activation of a CASP8/CASP3 signal transduction axis that in some cell types (including hepatocytes, pancreatic $\beta$ cells and multiple neoplastic cells) also involves MOMP, owing to the CASP8dependent activation of BID. ${ }^{152-157}$ Whether the apoptotic response to extracellular cues requires MOMP or not reportedly depends on the expression levels of X-linked inhibitor of apoptosis (XIAP), ${ }^{158,159}$ an ubiquitin ligase with multipronged cytoprotective functions. ${ }^{160,161}$ High amounts of XIAP prevent indeed the direct activation of CASP3 by CASP8, a block that can be circumvented by the release of diablo, IAPbinding mitochondrial protein (DIABLO, best known as second mitochondria-derived activator of caspases, SMAC) and other XIAP inhibitors into the cytosol following MOMP. ${ }^{158,159,162-164}$

It recently became clear that the main players in the RCD subroutine commonly referred to as necroptosis, which we previously defined as a caspase-independent, RIPK1- and RIPK3-dependent lethal signaling pathway initiated by death receptors, ${ }^{9,165}$ include not only RIPK1 and RIPK3, as initially thought, ${ }^{120,121,131,166-169}$ but also MLKL. ${ }^{104,170-179}$ The kinase activity of RIPK1 is required for necroptosis as induced by multiple stimuli, including death receptor ligation in the presence of caspase inhibitors. ${ }^{128-131,169,180}$ Conversely, catalytically inactive and Nec-1-bound RIPK1 inhibits the necroptotic response of CASP8-incompetent cells to Toll-like receptor (TLR) agonists or type I interferons, which relies not only on RIPK3 but also on TLR adaptor molecule 1 (TICAM1, best known as TRIF). ${ }^{181-184}$ In the absence of RIPK1, TLR agonists and type I interferons trigger necroptosis even in caspase-competent cells, ${ }^{182,183}$ suggesting that RIPK1 can inhibit necroptotic RCD as induced by these stimuli at two distinct levels. Furthermore, RIPK1 tonically suppresses CASP8 and RIPK3 activation in developmental scenarios independent of its kinase activity. ${ }^{183,185,186}$ This explains why Ripk $1^{-/-}$mice fail to survive to adulthood even in the absence of Fas (TNFRSF6)-associated via death domain (Fadd), which is required for CASP8 activation by extracellular cues, but mature normally in the absence of both Ripk3 and Fadd or Casp8. ${ }^{183}$ Other instances of necroptosis, such as those promoted by Z-DNA-binding protein 1 (ZBP1) in response to viral infection, appear to proceed independently of RIPK1. ${ }^{187}$ Upon phosphorylation by RIPK3, MLKL has a critical, non-redundant role in necroptosis. ${ }^{177,179}$ Phosphorylated MLKL forms indeed oligomers that translocate to cellular membranes (including the plasma membrane) and bind 
specific phospholipids, resulting in the loss of barrier function. ${ }^{170,171,174,175,188}$

Recent data argue against an essential role for mitochondria in necroptosis. Indeed, parkin RBR E3 ubiquitin protein ligase (PARK2)-overexpressing cells depleted of the vast majority of mitochondria upon the induction of mitophagy (by means of a mitochondrial uncoupler) become resistant to inducers of MOMP-dependent RCD, but remain sensitive to TNFR1 ligation in the presence of Z-VAD-fmk (a conventional trigger of necroptosis). ${ }^{189}$ Moreover, contrary to initial beliefs, ${ }^{190}$ the lethal activity of RIPK3 is not influenced by the absence of phosphoglycerate mutase family member 5 (PGAM5) and dynamin 1 like (DNM1L, best known as dynamin-related protein 1, DRP1). ${ }^{104,172,176}$ Based on these results, the NCCD proposes here to redefine necroptosis as an RCD modality that critically depends on MLKL and on the kinase activity of RIPK1 (in some settings) and RIPK3. Of note, both RIPK1 and RIPK3 have been shown to regulate caspase activation, at least under some circumstances. ${ }^{186,191-193}$ Taken together, these observations suggest that the signal transduction cascades responsible for the initiation of apoptosis and necroptosis are highly interconnected.

Necroptosis is actively inhibited by a supramolecular complex containing CASP8, FADD and the long isoform of CASP8 and FADD-like apoptosis regulator (CFLAR, best known as cellular FLICE inhibitor protein, C-FLIP), ${ }^{194-197}$ three key components of caspase-dependent RCD initiated by death receptors. ${ }^{198-203}$ Taken together with the notion that the absence of either Ripk3, Casp8 or Fadd fails to rescue Ripk1 ${ }^{-/-}$mice from neonatal lethality, ${ }^{180,185}$ these results pointed to the existence of a switch mechanism that regulates cell fate upon TNFR1 ligation. ${ }^{204,205}$ Intriguingly, such switch may not operate in all cell types, as demonstrated by the fact that Ripk $1^{-/-}$intestinal epithelial cells are fully rescued by the concomitant absence of Casp8 (Peter Vandenabeele, personal communication).

Recent data obtained with genetically engineered RIPK1 and RIPK3 variants indicate that the catalytic pathways activated in response to death receptor ligation depend on the availability of CASP8, FADD and MLKL. ${ }^{206}$ In comparatively more physiologic conditions, however, the fate of cells exposed to death receptor ligands may be determined by the activation kinetics of mitogen-activated protein kinase kinase kinase 7 (MAP3K7, best known as TGF $\beta$-activated kinase 1 , TAK1), ${ }^{192,193,207}$ which normally initiates a cytoprotective response centered around the transcription factor NF- $\kappa B$ and autophagy, ${ }^{208-212}$ or by the availability of baculoviral IAP repeat containing (BIRC) family members, ${ }^{192,193}$ ubiquitin ligases with a central role in TNFR1 signaling. ${ }^{213}$ In line with this notion, cells treated with a SMAC mimetic (resulting in the depletion of BIRC2 and BIRC3) or a chemical TAK1 inhibitor (NP-009245) reportedly respond to TNFR1 ligation by activating caspases in a RIPK1-dependent manner. ${ }^{192}$ Taken together, these observations indicate that death receptors generate a lethal stimulus that can be propagated along several signal transduction cascades. Thus, caution should be used in evaluating necroptotic instances of cell death based on their sensitivity to Nec-1 only.

Another variant of RCD that often, although not always, manifests with a necrotic morphotype critically relies on
CYPD. ${ }^{214}$ At present, CYPD is the sole genetically confirmed component of the permeability transition pore complex (PTPC) in the mammalian system. ${ }^{132,133,135,215-217}$ The term PTPC generally refers to a supramolecular complex operating at the junctions between the inner and outer mitochondrial membrane to cause the so-called 'mitochondrial permeability transition' (MPT), an abrupt increase in the permeability of the inner mitochondrial membrane to small solutes triggered by cytosolic $\mathrm{Ca}^{2+}$ overload or oxidative stress. ${ }^{214,218-221}$ Unlike MOMP, ${ }^{205,222-224}$ MPT seals the cell fate independently of caspase activation. ${ }^{133,225,226}$ Nonetheless, MPT-driven RCD can manifest with (at least some) morphologic features associated with apoptosis, ${ }^{10,227,228}$ corroborating the limited informative value of cell death classifications solely based on morphology. The NCCD recommends the use of the term 'MPT-driven RCD' for instances of cell death whose course can be influenced with the genetic or pharmacologic inhibition of CYPD or other components of the PTPC. Of note, CYPD surely does not constitute the long-sought pore-forming unit of the PTPC, which most likely involves subunits of the so-called 'ATP synthasome', the supramolecular complex that imports ADP and inorganic phosphate into the mitochondrial matrix, catalyzes ATP synthesis and exports ATP back to the mitochondrial intermembrane space (from where it can easily reach the cytosol). ${ }^{229-234}$ Perhaps, the central role of CYPD in MPT-driven RCD reflects its ability to control the $\mathrm{Ca}^{2+}$ buffering capacity of the mitochondrial network. ${ }^{235,236}$ This hypothesis has not yet been formally addressed.

Two forms of RCD other than necroptosis and MPT-driven RCD have recently attracted attention as potential targets for the development of cytoprotective interventions, namely 'parthanatos' and 'ferroptosis'. ${ }^{33}$ The main molecular features of parthanatos are the hyperactivation of PARP1 and the release of apoptosis-inducing factor, mitochondrion-associated, 1 (AIFM1) from the mitochondria. ${ }^{237-240}$ Interestingly, although TNFR1-driven necroptosis and parthanatos have been suggested to constitute completely independent RCD subroutines, ${ }^{241}$ this issue remains a matter of debate. ${ }^{101,242}$ Possibly, such a controversy originates from the ability of some insults to simultaneously trigger necroptosis and parthanatos, at least in some model systems. ${ }^{243}$ Ferroptosis has been defined as an iron-dependent form of RCD under the control of glutathione peroxidase 4 (GPX4). ${ }^{244-247}$ Both the pharmacologic and genetic inhibition of CYPD fail to prevent ferroptosis as triggered by erastin, a small molecule that is selectively lethal for cancer cells expressing oncogenic variants of Harvey rat sarcoma viral oncogene homolog (HRAS). ${ }^{246,248}$ This suggests that ferroptosis and MPT-driven RCD constitute independent variants of RCD. Of note, erastin inhibits system $\mathrm{x}_{\mathrm{C}}^{-}$, an heterodimeric antiporter of the plasma membrane that normally exchanges intracellular glutamate for extracellular cysteine, resulting in glutathione depletion and iron-dependent accumulation of reactive oxygen species. ${ }^{247}$ A similar cascade of events contributes to (but is not the sole etiological determinant of) the death of neurons exposed to glutamate. This necrotic instance of RCD has previously been referred to as oxytosis. ${ }^{121,249}$ Besides inhibiting system $\mathrm{x}_{\mathrm{C}}^{-}$, glutamate can trigger MPT-driven RCD upon the hyperactivation of ionotropic receptors, a neurotoxic process commonly known as excitotoxicity. 250,251 
Caspase-unrelated variants of RCD include 'autophagic cell death', which (among other processes) is biochemically associated with the lipidation of microtubule-associated protein 1 light chain 3 (MAP1LC3, best known as LC3) and the degradation of sequestosome 1 (SQSTM1, best known as p62). ${ }^{76}$ The NCCD recommends using this term only for RCD instances that can be influenced by the pharmacologic or genetic interventions targeting at least two distinct components of the molecular machinery for autophagy. 9,76 While autophagy accompanies RCD in a vast number of pathophysiologic settings, ${ }^{36,50,252}$ it truly contributes to the cellular demise only in a few of them. ${ }^{69,70,76,253-259}$ Beth Levine's laboratory has recently discovered a bona fide instance of autophagic cell death that relies on the plasma membrane $\mathrm{Na}^{+} / \mathrm{K}^{+}$-ATPase, and dubbed it 'autosis'. ${ }^{255}$ Of note, autosis occurs not only in vitro, in cells exposed to cell permeant autophagy-inducing peptides, but also in vivo, in the brain of rats subjected to an ischemic insult. ${ }^{255}$ It remains to be determined whether all cases of autophagic cell death require the $\mathrm{Na}^{+} / \mathrm{K}^{+}$-ATPase or not. If so, the terms 'autosis' and 'autophagic cell death' would be synonymous. If not, autosis would constitute a special instance of autophagic cell death. ${ }^{260}$

Importantly, a growing body of evidence indicates that the pharmacologic or genetic inhibition of the processes that are commonly considered as essential for cell death execution often does not avoid the demise of mammalian cells, but rather alters its kinetics and biochemical (and morphologic) manifestations. Thus, in many experimental paradigms (in vitro and in vivo), Z-VAD-fmk and more specific CASP3 inhibitors administered as therapeutic (as opposed to prophylactic) ${ }^{77}$ interventions fail to significantly limit primary RCD, in spite of the fact that they efficiently limit caspase activation. ${ }^{261-265}$ In some of these scenarios, RCD overtly manifests with alternative biochemical processes, including RIPK1, RIPK3 or PARP1 activation, and (at least in part) can be influenced by agents that interfere with these pathways, including Nec-1, 3-aminobenzamide (a PARP1-targeting agent) and necrosulfonamide (an inhibitor of human MLKL). ${ }^{261,263,264}$ However, the proportion of cells eventually succumbing to RCD does not change. The depletion of BIRC2/BIRC3, RIPK1, RIPK3 or MLKL, and the administration of NP-009245, Nec-1 or geldanamycin (which indirectly destabilizes RIPK 1$)^{266}$ reportedly changes the kinetics of necroptosis and its biochemical profile, that is, it allows for caspase activation, yet fails to block the cellular demise. ${ }^{101,103,104,192,267}$ Along similar lines, 3-aminobenzamide and 4-amino-1,8-naphthalimide (another PARP1 inhibitor) can convert the cytotoxic response to alkylating DNA damage or TNFR1 ligation from a caspase-independent one to apoptosis, manifesting with caspase activation. ${ }^{105-107}$

These observations indicate that, similar to their morphologic counterparts, the biochemical manifestations of cell death can be altered in the absence of efficient cytoprotection.

\section{RCD and Stress Adaptation}

Cells subjected to perturbations of intracellular or extracellular homeostasis almost invariably mount a tightly coordinated response aimed at (1) the removal of the initiating stimulus (when possible), (2) the repair of molecular and/or organelle damage, and (3) eventually, the re-establishment of physiologic conditions. ${ }^{34-38,42,57,268}$ When these objectives cannot be attained, cells generally undergo RCD as a means to preserve the homeostasis of the whole organism (or colony, in the case of yeast cells). Two mutually exclusive models can be put forward to explain how adaptive stress responses promote RCD when unsuccessful. First, a 'conversion model' postulates that RCD-inhibitory signals cease at some stage of the adaptive response and are replaced by RCD-promoting ones. Second, a 'competition model' hypothesizes that RCDinhibitory and -promoting signals coexist and counteract with each other starting from the detection of microenvironmental alterations, but at some stage the latter predominate over the former (Figure 2). Although data formally favoring one of these models over the other are lacking, circumstantial evidence suggests that RCD-promoting signals are activated when RCDinhibitory mechanisms are still operational. ${ }^{36,159,252,269-273}$

Based on this conceptual construction, the NCCD recommends to use the term 'initiation' to indicate the RCD-causing events that are reversible, that is, that do not irrevocably commit cells to die as they occur when adaptive responses are still operational. In addition, we encourage the use of the expression 'execution' for referring to the processes that irreversibly and causally seal the cell fate, and the term 'propagation' to indicate the processes that link primary (stimulus-dependent) RCD to the stimulus-independent initiation of a secondary RCD wave, including the release of DAMPs and the consequent inflammatory response (Figure 3). The blockage of RCD-initiating mechanisms by either pharmacologic or genetic means has been associated with consistent degrees of cytoprotection in rodent models representing various human diseases linked to unwarranted cell death. For instance, this applies to the whole-body ablation of Ppif (the CYPD-coding gene), ${ }^{132-134,274}$ Ripk3 ${ }^{167,176,274-278}$ and Mlkl, ${ }^{176,177}$ as well as to the administration of chemical CYPD inhibitors (i.e., cyclosporin A and sanglifehrin A) ${ }^{274}$ and Nec-1. ${ }^{274,277}$ Conversely, pharmacologic and genetic interventions expected to interrupt RCD at late steps of the process (when cells are commonly considered as committed to die) generally fail to confer significant long-term cytoprotection in mammalian models, casting doubts on the actual etiological value of these steps for RCD. Thus, Casp3 $^{-/-}$, Casp9 $^{-/-}$and Apaf1 ${ }^{-/-}$mice display a consistent hyperplasia of the central nervous system associated with reduced amounts of PCD in specific cerebral areas, resulting in embryonic or perinatal lethality. ${ }^{279-284}$ However, the neuronal phenotype of Casp3 $3^{-/-}$mice does not develop in all genetic backgrounds, ${ }^{89,285,286}$ and the penetrance of the perinatal lethality associated with the Apaf1 $1^{-/-}$genotype is incomplete (as some animals survive through 10 months of age). ${ }^{88,287}$ Moreover, the developmental death of interdigital cells (which generally manifests with biochemical correlates of apoptosis) occurs close to normally (allowing for normal morphogenesis) in mice bearing a homozygous loss-offunction mutation in Apaf1, and in mice exposed to broadspectrum caspase inhibitors. ${ }^{80}$ In these settings, however, the demise of interdigital cells cannot be detected by the terminal-deoxynucleotidyl-mediated dUTP nick end-labeling (TUNEL) assay, measuring caspase-dependent DNA 


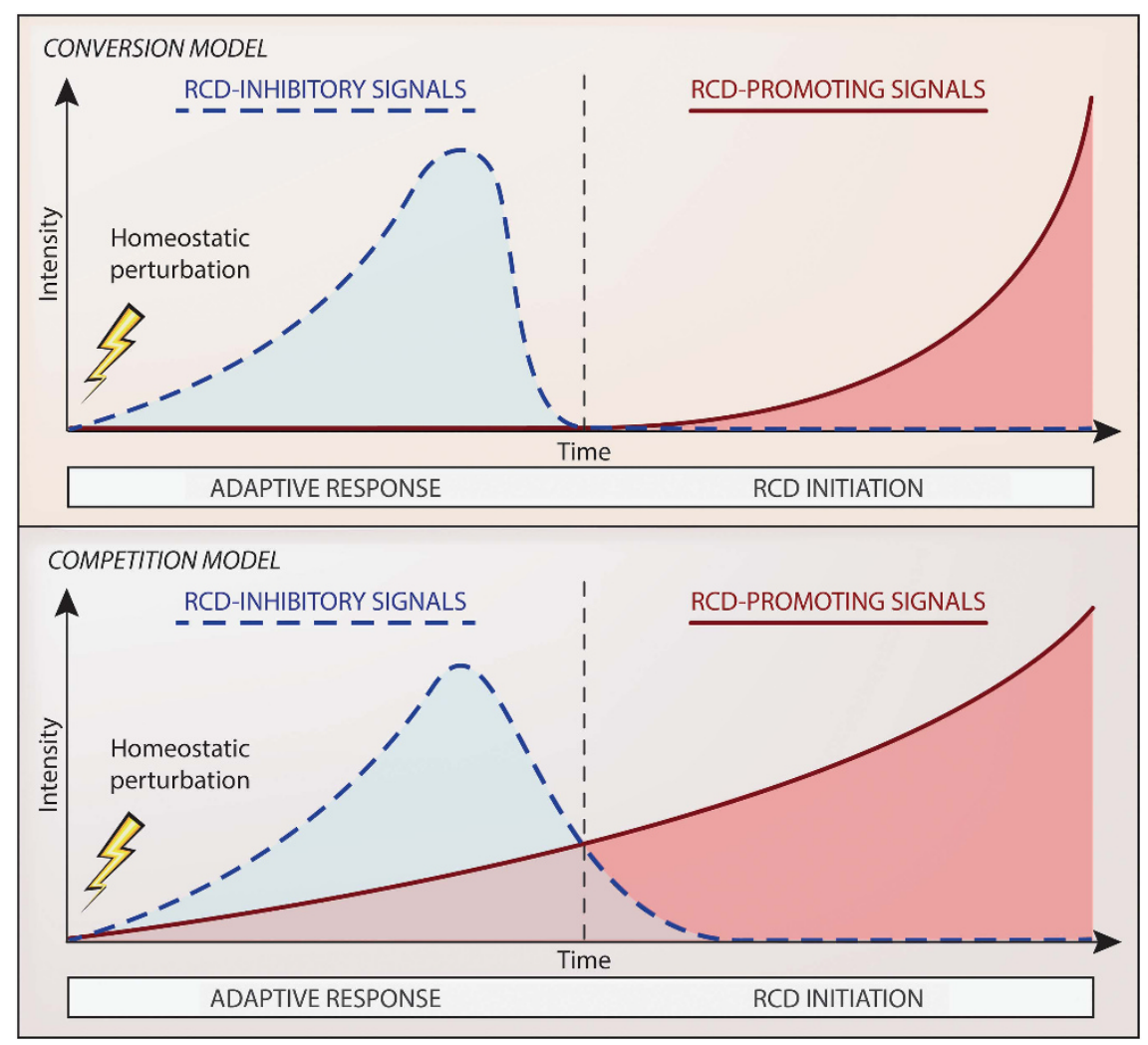

Figure 2 Regulated cell death and adaptive stress responses. Regulated cell death (RCD) is often initiated in the context of unsuccessful responses to perturbations of intracellular or extracellular homeostasis. Two mutually exclusive models can be put forward to explain how failing responses to stress initiate RCD (which in many instances constitutes a means to preserve the homeostasis of the whole organism or colony). First, according to a 'conversion model', RCD-inhibitory signals simply cease at some stage of the adaptive response and are substituted by RCD-promoting ones. Second, a 'competition model' postulates that RCD-inhibitory and -promoting signals coexist and counteract each other starting from the very detection of microenvironmental alterations, and at some stage the latter predominate over the former. Circumstantial evidence favors the 'competition model' in a majority of experimental scenarios

fragmentation. ${ }^{80}$ Conversely, the simultaneous ablation of $B a x$ and $B a k 1^{288}$ or Bcl2/11 and Bmf (encoding two BH3-only proteins involved in MOMP initiation) ${ }^{289-291}$ truly prevents the programmed demise of several cell types, causing their persistence throughout adult life..$^{292,293}$ These observations are compatible with the hypothesis that the phenotype associated with some defects in the molecular cascades linking MOMP to caspase activation originates from a delay, rather than from bona fide inhibition, of PCD. Moreover they suggest that RCD, be it programmed or caused by microenvironmental perturbations, can only be avoided by interventions that target upstream steps of the process.

Caution should also be taken in inferring the actual etiological value of caspases in RCD based on the therapeutic administration of Z-VAD-fmk or other broad-spectrum caspase inhibitors. Caspase blockers have indeed been associated with (at least some degree of) cytoprotection in rodent models of various human diseases linked to the excessive loss of parenchymal cells. These pathologies include, but are not limited to, neurodegenerative disorders, ${ }^{294-298}$ traumatic events $^{299,300}$ and ischemia/reperfusion injuries of the central nervous system, heart and kidney. ${ }^{301-304}$ Nonetheless, Z-VAD-fmk and similar compounds inhibit not only several caspases but also a wide panel of non-caspase proteases that participate in the initiation of RCD, such as calpains. ${ }^{305,306}$ Moreover, CASP3, caspase-6 (CASP6) and caspase-7
(CASP7) (i.e., the putative executioners of apoptosis) have been involved in feedforward circuitries that amplify lethal cues leading to MOMP, ${ }^{307-310}$ implying that their inhibition may also counteract the initiation of RCD. Finally, in models of this type it is difficult to discriminate between the primary wave of RCD (promoted by experimental interventions) and the delayed, secondary demise of parenchymal cells caused by DAMPs (directly or upon the establishment of inflammation). ${ }^{73,311-313}$ The cytoprotective effects that Z-VAD-fmk-like chemicals exert in similar scenarios, which are most reliably evaluated by histological determinations or functional tests, might therefore reflect their ability to block the initiation of DAMP- and inflammation-driven secondary RCD rather than the execution of stimulus-induced, primary RCD. In line with this notion, consistent cytoprotection has also been achieved in vivo by means of anti-inflammatory agents, even when these compounds do not directly influence RCD. ${ }^{314-317}$ Taken together, these observations reinforce the notion that caspases may not mediate RCD but simply accelerate its course, at least in the mammalian system.

Apparently at odds with the role of PARP1 in the execution of parthanatos, both the Parp1 ${ }^{-/}$genotype and the administration of (relatively unselective) PARP inhibitors have been associated with bona fide cytoprotection in rodent models of ischemia/reperfusion injury and retinal degeneration. ${ }^{318-321}$ These observations suggest that 


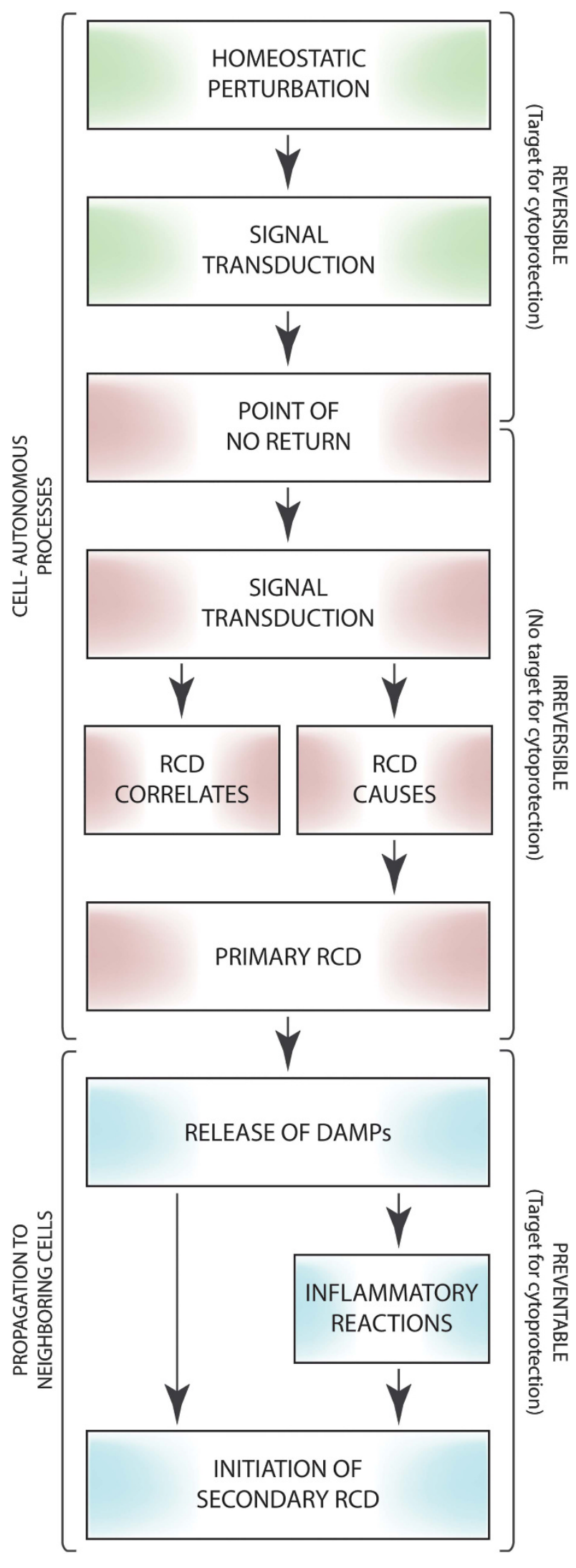

Cell Death and Differentiation
PARP1 and/or other members of the PARP family also participate in the initiation of RCD. Alternatively, the inhibition of PARP1 may limit the release of DAMPs or the consequent inflammatory response, at least in some pathophysiologic settings. Further experiments are required to clarify these possibilities.

\section{Concluding Remarks}

As discussed above, the processes that until now were thought to mediate RCD most often do not causally underpin the cellular demise but represent biochemical manifestations of it. A growing body of data indicates indeed that the bona fide executioners of RCD, that is, the processes that directly drive cells across the boundary between life and death are less characterized, less inhibitable and perhaps more homogeneous than previously thought. ${ }^{322}$ In line with this theoretical construction, here the NCDD proposes to use the term 'initiation' to refer to all the steps in the RCD cascade that are reversible, that is, which occur before cells make an irrevocable commitment to die. An attentive reinterpretation of the literature suggests that actual cytoprotection can only be achieved with pharmacologic or genetic interventions that inhibit or outcompete lethal signals at this stage, when adaptive responses to stress are still operational. Interestingly, some cells manifesting biochemical and morphologic features associated with late-stage RCD (including partial MOMP, caspase activation and blebbing) appear to recover (upon removal of the RCD-initiating insult) and replicate, a process that has been dubbed 'anastasis' (from the ancient Greek ' $\alpha \nu \sigma \tau \alpha \sigma \imath \varsigma$ ', meaning 'raising to life'). ${ }^{323,324}$ This suggests that the actual point of no return in the signaltransduction cascades leading to RCD may exhibit at least some degree of context dependency.

In the vast majority of scientific reports, RCD is measured in vitro 24-96h after stimulation, whereas the most reliable assessment of RCD in vivo is based upon histologic determinations or functional tests performed days, if not weeks or months, after such experimental interventions. In the former

Figure 3 Initiation, execution and propagation of regulated cell death. The term 'execution' has largely been used to indicate the processes that (were thought to) mediate regulated cell death (RCD), such as the massive activation of CASP3 in the course of apoptosis. Conversely, the word 'initiation' has generally been used to refer to the signal transduction events that trigger executioner mechanisms, such as the activation of CASP8 or CASP9, both of which normally impinge on CASP3. Upon an attentive re-evaluation of the available literature, the NCCD recommends caution in attributing a specific process a bona fide causative value in the execution of cell death. In addition, the NCCD proposes to use the term 'initiation' with a pragmatic connotation, that is, to indicate the steps in the cascades of events leading to RCD that are truly reversible, and the term 'propagation' to indicate the processes that link primary RCD to the insult-independent initiation of a secondary wave of RCD, that is, the release of cytotoxic and proinflammatory factors, including damage-associated molecular patterns (DAMPs), by dying cells and their consequences. Based on this conceptual construction, only pharmacologic and genetic interventions that target the initiation phase exert bona fide cytoprotective effects, that is, truly inhibit primary RCD rather than just delaying its course or changing its morphologic or biochemical correlates. Robust cytoprotection can also be achieved in vivo by the administration of anti-inflammatory agents and by measures that block DAMPs or their receptors. These maneuvers, however, appear to be efficient as they prevent the propagation of primary RCD or the initiation of secondary RCD 


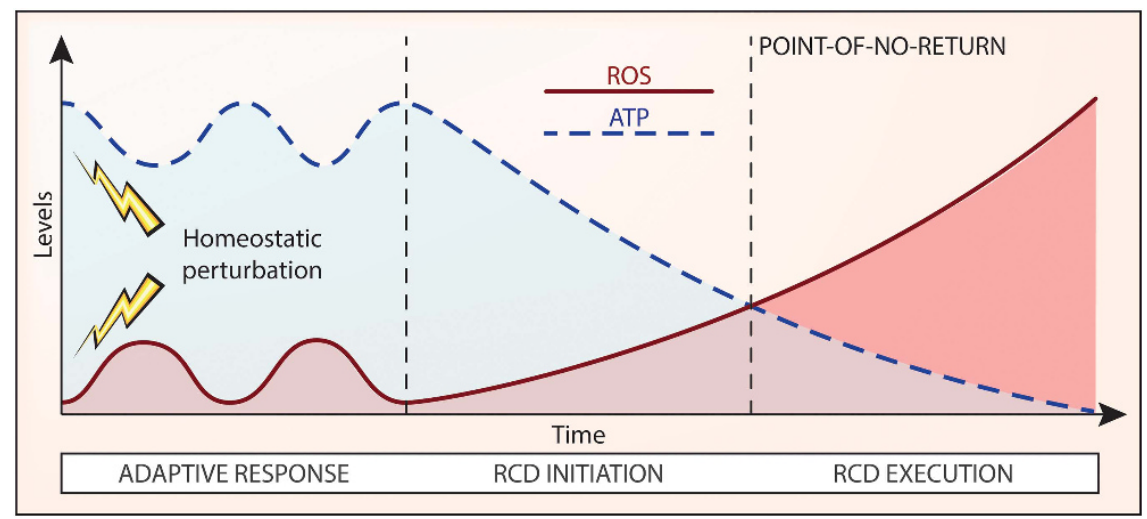

Figure 4 Declining ATP levels and redox alterations as a potential cause of regulated cell death. A growing amount of evidence indicates that the pharmacologic or genetic inhibition of the mechanisms that are commonly regarded as the executioners of regulated cell death (RCD) changes the kinetics of the process while altering its morphologic and biochemical manifestations, but fails to mediate bona fide long-term cytoprotection. It is therefore difficult to evaluate the actual causes that push cells beyond the point-ofno-return between life and death, especially as it remains to be formally demonstrated where the frontier between reversible alterations of homeostasis and the irreversible degeneration of cellular functions stands. ATP is required for a wide panel of vital activities, including the maintenance of the ionic equilibrium across the plasma membrane, implying that the drop of ATP concentrations below a specific threshold level may irremediably compromise the ability of cells to maintain structural integrity (which is the most reliable marker of cell death currently available). Along similar lines, variations in the oxidative potential of the intracellular milieu not only inhibit several enzymatic activities, including mitochondrial ATP synthesis, but also cause direct structural damage to organelles and membranes. We therefore hypothesize that declining ATP levels and a compromised redox homeostasis may constitute common causes of cell death in many RCD models. ROS, reactive oxygen species

scenario, investigators can collect valuable kinetic data but are unable to estimate the true long-term survival of cells exposed to perturbations of homeostasis. In the second scenario, it is difficult to discriminate between the interruption of primary RCD and the inhibition of DAMP-driven inflammatory reactions and secondary RCD. This may have profound mechanistic and therapeutic implications. Indeed, retarding the demise of a cell that has already committed to die in an irreversible manner, and the biochemical manifestations of such death, may have limited cytoprotective effects for the cell in question, but may impact on the emission of DAMPs and hence significantly influence RCD propagation. Thus, considerable degrees of cytoprotection might be attained by means of agents that interrupt lethal cues at (or before) RCD initiation (when adaptive stress responses are still functional) combined with strategies that inhibit propagation (e.g., chemicals that favor RCD instances associated with a limited release of DAMPs, DAMP-neutralizing measures, anti-inflammatory agents). The superior beneficial effects of cyclosporin A may indeed stem from its ability to inhibit MPT-driven RCD and simultaneously exert a robust antiinflammatory activity. ${ }^{325,326}$

If caspases and other enzymes commonly thought to mediate RCD in mammalian cells only underpin its manifestations, what are the true causes of cell death? Although the concentration of ATP is preserved (or even increases to some extent) in the course of adaptive stress responses, ${ }^{247,327}$ circumstantial evidence points to dropping ATP levels, which at some point abolish the activity of all ATP-dependent enzymes (including various transporters that maintain ionic balance at the plasma membrane) and a compromised redox balance (which inactivates various enzymes and causes oxidative molecular damage to organelles and membranes) as central players in the execution of RCD (Figure 4). ${ }^{328}$ Alternatively, one or more hitherto uncharacterized mechanism(s) may causally underpin RCD in all its manifestations. Further experiments are required to explore these possibilities.
At odds with mammalian models, Caenorhabditis elegans and $D$. melanogaster are truly protected by Z-VAD-fmk and by the genetic inhibition of caspase orthologs and other proteins involved in the postmitochondrial phase of apoptosis. ${ }^{329-335}$ This may indicate that the signal transduction cascades underlying RCD are interconnected in a different manner in mammals and non-mammalian organisms. Alternatively, the actual requirement of caspases for (at least some instances of) RCD might have been concealed by the evolutionary expansion of the caspase family. Both the human and murine genome encode indeed 14 distinct caspases, ${ }^{336,337}$ and it seems unlikely that Z-VAD-fmk and other pharmacologic or genetic interventions may simultaneously inhibit all of them in an efficient manner.

Until these uncertainties have been resolved, the NCCD recommends that investigators focus on essential aspects of cell death; first of all its actual occurrence. It appears indeed that measuring the functional status or subcellular localization of RCD-relevant proteins including (but not limited to) caspases, RIPK1, RIPK3, MLKL, CYPD, PARP1 and GPX4, can provide insights into the mechanisms that accompany (and regulate the kinetics of) cellular demise, but not into those that truly push cells beyond the point-of-no-return separating life and death. Precisely defining where this border stands from a bioenergetic and metabolic perspective may facilitate the development of novel and efficient cytoprotective agents for clinical use.

\section{Conflict of Interest}

The authors declare no conflict of interest.

1. Mazzarello P. A unifying concept: the history of cell theory. Nat Cell Biol 1999; 1: E13-E15.

2. Cotter TG. Apoptosis and cancer: the genesis of a research field. Nat Rev Cancer 2009; 9: 501-507.

3. Schweichel JU, Merker HJ. The morphology of various types of cell death in prenatal tissues. Teratology 1973; 7: 253-266.

4. Vaux DL. Apoptosis timeline. Cell Death Differ 2002; 9: 349-354. 
5. Pearson H. 'Virophage' suggests viruses are alive. Nature 2008; 454: 677.

6. La Scola B, Audic S, Robert C, Jungang L, de Lamballerie X, Drancourt M et al. A giant virus in amoebae. Science 2003; 299: 2033.

7. La Scola B, Desnues C, Pagnier I, Robert C, Barrassi L, Fournous G et al. The virophage as a unique parasite of the giant mimivirus. Nature 2008; 455: 100-104.

8. Raoult D, Forterre P. Redefining viruses: lessons from Mimivirus. Nat Rev Microbiol 2008; 6: 315-319.

9. Galluzzi L, Vitale I, Abrams JM, Alnemri ES, Baehrecke EH, Blagosklonny MV et al. Molecular definitions of cell death subroutines: recommendations of the Nomenclature Committee on Cell Death. Cell Death Differ 2012; 19: 107-120.

10. Kroemer G, Galluzzi L, Vandenabeele P, Abrams J, Alnemri ES, Baehrecke EH et al. Classification of cell death: recommendations of the Nomenclature Committee on Cell Death 2009. Cell Death Differ 2009; 16: 3-11.

11. Galluzzi L, Maiuri MC, Vitale I, Zischka H, Castedo M, Zitvogel L et al. Cell death modalities: classification and pathophysiological implications. Cell Death Differ 2007; 14: 1237-1243.

12. Poon IK, Lucas CD, Rossi AG, Ravichandran KS. Apoptotic cell clearance: basic biology and therapeutic potential. Nat Rev Immunol 2014; 14: 166-180.

13. Hochreiter-Hufford A, Ravichandran KS. Clearing the dead: apoptotic cell sensing, recognition, engulfment, and digestion. Cold Spring Harb Perspect Biol 2013; 5: a008748.

14. Underhill DM, Goodridge HS. Information processing during phagocytosis. Nat Rev Immunol 2012; 12: 492-502.

15. Overholtzer M, Mailleux AA, Mouneimne G, Normand G, Schnitt SJ, King RW et al. A nonapoptotic cell death process, entosis, that occurs by cell-in-cell invasion. Cell 2007; 131: 966-979.

16. Galluzzi L, Kepp O, Kroemer G. Mitochondria: master regulators of danger signalling. Nat Rev Mol Cell Biol 2012; 13: 780-788.

17. Klionsky DJ, Abdalla FC, Abeliovich $\mathrm{H}$, Abraham RT, Acevedo-Arozena A, Adeli K et al. Guidelines for the use and interpretation of assays for monitoring autophagy. Autophagy 2012; 8: 445-544.

18. Kepp O, Galluzzi L, Lipinski M, Yuan J, Kroemer G. Cell death assays for drug discovery. Nat Rev Drug Discov 2011; 10: 221-237.

19. Zhang $Q$, Raoof $M$, Chen $Y$, Sumi $Y$, Sursal $T$, Junger $W$ et al. Circulating mitochondrial DAMPs cause inflammatory responses to injury. Nature 2010; 464: 104-107.

20. Galluzzi L, Aaronson SA, Abrams J, Alnemri ES, Andrews DW, Baehrecke EH et al. Guidelines for the use and interpretation of assays for monitoring cell death in higher eukaryotes. Cell Death Differ 2009; 16: 1093-1107.

21. Tasdemir E, Galluzzi L, Maiuri MC, Criollo A, Vitale I, Hangen E et al. Methods for assessing autophagy and autophagic cell death. Methods Mol Biol 2008; 445: 29-76.

22. Krysko DV, Vanden Berghe T, D'Herde K, Vandenabeele P. Apoptosis and necrosis: detection, discrimination and phagocytosis. Methods 2008; 44: 205-221.

23. Green DR, Kroemer G. Pharmacological manipulation of cell death: clinical applications in sight? J Clin Invest 2005; 115: 2610-2617.

24. Vanden Berghe T, Grootjans S, Goossens V, Dondelinger Y, Krysko DV, Takahashi N et al. Determination of apoptotic and necrotic cell death in vitro and in vivo. Methods 2013; 61: 117-129.

25. Grootjans S, Goossens V, Vandenabeele P, Vanden Berghe T. Methods to study and distinguish necroptosis. In: Cell Death in Biology and Diseases: Necrotic Cell Death. Humana Press, SpringerNew York, NY, USA, 2014, pp 335-361.

26. Long JS, Ryan KM. New frontiers in promoting tumour cell death: targeting apoptosis, necroptosis and autophagy. Oncogene 2012; 31: 5045-5060.

27. MacFarlane M. Cell death pathways - potential therapeutic targets. Xenobiotica 2009; 39 : 616-624.

28. Reed JC. Drug insight: cancer therapy strategies based on restoration of endogenous cell death mechanisms. Nat Clin Pract Oncol 2006; 3: 388-398.

29. Brenner C, Galluzzi L, Kepp O, Kroemer G. Decoding cell death signals in liver inflammation. J Hepatol 2013; 59: 583-594.

30. Zelenay S, Reis e Sousa C. Adaptive immunity after cell death. Trends Immunol 2013; 34: 329-335.

31. Sims GP, Rowe DC, Rietdijk ST, Herbst R, Coyle AJ. HMGB1 and RAGE in inflammation and cancer. Annu Rev Immunol 2010; 28: 367-388.

32. Zitvogel L, Kepp O, Kroemer G. Decoding cell death signals in inflammation and immunity. Cell 2010; 140: 798-804.

33. Galluzzi L, Kepp O, Krautwald S, Kroemer G, Linkermann A. Molecular mechanisms of regulated necrosis. Semin Cell Dev Biol 2014; doi:10.1016/j.semcdb.2014.02.006.

34. Bhattacharyya S, Yu H, Mim C, Matouschek A. Regulated protein turnover: snapshots of the proteasome in action. Nat Rev Mol Cell Biol 2014; 15: 122-133.

35. Fulda S, Gorman AM, Hori O, Samali A. Cellular stress responses: cell survival and cell death. Int J Cell Biol 2010; 2010: 214074.

36. Kroemer G, Marino G, Levine B. Autophagy and the integrated stress response. Mol Cell 2010; 40: 280-293.

37. Richter K, Haslbeck M, Buchner J. The heat shock response: life on the verge of death. Mol Cell 2010; 40: 253-266.

38. Spriggs KA, Bushell M, Willis AE. Translational regulation of gene expression during conditions of cell stress. Mol Cell 2010; 40: 228-237.

39. Haynes CM, Fiorese CJ, Lin YF. Evaluating and responding to mitochondrial dysfunction: the mitochondrial unfolded-protein response and beyond. Trends Cell Biol 2013; 23: 311-318.
40. Choi AM, Ryter SW, Levine B. Autophagy in human health and disease. N Engl J Med 2013; 368: 651-662.

41. Jensen MB, Jasper $\mathrm{H}$. Mitochondrial proteostasis in the control of aging and longevity. Cell Metab 2014; 20: 214-225.

42. Galluzzi L, Bravo-San Pedro JM, Kroemer G. Organelle-specific initiation of cell death Nat Cell Biol 2014; 16: 728-736.

43. Mizushima N, Levine B, Cuervo AM, Klionsky DJ. Autophagy fights disease through cellular self-digestion. Nature 2008; 451: 1069-1075.

44. Amelio I, Melino G, Knight RA. Cell death pathology: cross-talk with autophagy and its clinical implications. Biochem Biophys Res Commun 2011; 414: 277-281.

45. Czabotar PE, Lessene G, Strasser A, Adams JM. Control of apoptosis by the BCL-2 protein family: implications for physiology and therapy. Nat Rev Mol Cell Biol 2014; 15 49-63.

46. Gogvadze V, Orrenius S, Zhivotovsky B. Mitochondria as targets for cancer chemotherapy. Semin Cancer Biol 2009; 19: 57-66.

47. Lindner AU, Concannon CG, Boukes GJ, Cannon MD, Llambi F, Ryan D et al. Systems analysis of $\mathrm{BCL} 2$ protein family interactions establishes a model to predict responses to chemotherapy. Cancer Res 2013; 73: 519-528.

48. Chipuk JE, Moldoveanu T, Llambi F, Parsons MJ, Green DR. The BCL-2 family reunion. Mol Cell 2010; 37: 299-310.

49. Rubinsztein DC, Codogno P, Levine B. Autophagy modulation as a potential therapeutic target for diverse diseases. Nat Rev Drug Discov 2012; 11: 709-730.

50. White E. Deconvoluting the context-dependent role for autophagy in cancer. Nat Rev Cancer 2012; 12: 401-410.

51. Taylor RC, Cullen SP, Martin SJ. Apoptosis: controlled demolition at the cellular level. Nat Rev Mol Cell Biol 2008; 9: 231-241.

52. Lettre G, Hengartner MO. Developmental apoptosis in C. elegans: a complex CEDnario. Nat Rev Mol Cell Biol 2006; 7: 97-108.

53. Fuchs $Y$, Steller $H$. Programmed cell death in animal development and disease. Cell 2011; 147: 742-758.

54. Delbridge AR, Valente LJ, Strasser A. The role of the apoptotic machinery in tumor suppression. Cold Spring Harb Perspect Biol 2012; 4: doi:10.1101/cshperspect.a008789.

55. Strasser A, Jost PJ, Nagata $S$. The many roles of FAS receptor signaling in the immune system. Immunity 2009; 30: 180-192.

56. Peter ME, Budd RC, Desbarats J, Hedrick SM, Hueber AO, Newell MK et al. The CD95 receptor: apoptosis revisited. Cell 2007; 129: 447-450.

57. Walczak H. Death receptor-ligand systems in cancer, cell death, and inflammation. Cold Spring Harb Perspect Biol 2013; 5: a008698.

58. Lockshin RA, Williams CM. Programmed cell death II. Endocrine potentiation of the breakdown of the intersegmental muscles of silkmoths. J Insect Phys 1964; 10: 643-649.

59. Kerr JF, Wyllie AH, Currie AR. Apoptosis: a basic biological phenomenon with wide-ranging implications in tissue kinetics. Br J Cancer 1972; 26: 239-257.

60. Clarke PG. Developmental cell death: morphological diversity and multiple mechanisms. Anat Embryol (Berl) 1990; 181: 195-213.

61. Igney FH, Krammer PH. Death and anti-death: tumour resistance to apoptosis. Nat Rev Cancer 2002; 2: 277-288.

62. Bellamy CO, Malcomson RD, Harrison DJ, Wyllie AH. Cell death in health and disease: the biology and regulation of apoptosis. Semin Cancer Biol 1995; 6: 3-16.

63. Tracy K, Baehrecke EH. The role of autophagy in Drosophila metamorphosis. Curr Top Dev Biol 2013; 103: 101-125.

64. Nezis IP, Shravage BV, Sagona AP, Lamark T, Bjorkoy G, Johansen T et al. Autophagic degradation of dBruce controls DNA fragmentation in nurse cells during late Drosophila melanogaster oogenesis. J Cell Biol 2010; 190: 523-531.

65. Denton D, Shravage B, Simin R, Baehrecke EH, Kumar S. Larval midgut destruction in Drosophila: not dependent on caspases but suppressed by the loss of autophagy. Autophagy 2010; 6: 163-165.

66. Denton D, Shravage B, Simin R, Mills K, Berry DL, Baehrecke EH et al. Autophagy, not apoptosis, is essential for midgut cell death in Drosophila. Curr Biol 2009; 19: 1741-1746.

67. Berry DL, Baehrecke EH. Growth arrest and autophagy are required for salivary gland cell degradation in Drosophila. Cell 2007; 131: 1137-1148.

68. Baehrecke EH. Autophagy: dual roles in life and death? Nat Rev Mol Cell Biol 2005; 6: 505-510.

69. Denton D, Aung-Htut MT, Lorensuhewa N, Nicolson S, Zhu W, Mills K et al. UTX coordinates steroid hormone-mediated autophagy and cell death. Nat Commun 2013; 4: 2916.

70. Denton D, Chang TK, Nicolson S, Shravage B, Simin R, Baehrecke EH et al. Relationship between growth arrest and autophagy in midgut programmed cell death in Drosophila. Cell Death Differ 2012; 19: 1299-1307.

71. Roach HI, Clarke NM. Physiological cell death of chondrocytes in vivo is not confined to apoptosis. New observations on the mammalian growth plate. J Bone Joint Surg Br2000; 82: 601-613.

72. Kroemer G, Galluzzi L, Kepp O, Zitvogel L. Immunogenic cell death in cancer therapy. Annu Rev Immunol 2013; 31: 51-72.

73. Krysko DV, Garg AD, Kaczmarek A, Krysko O, Agostinis P, Vandenabeele P. Immunogenic cell death and DAMPs in cancer therapy. Nat Rev Cancer 2012; 12: 860-875.

74. Vandenabeele P, Galluzzi L, Vanden Berghe T, Kroemer G. Molecular mechanisms of necroptosis: an ordered cellular explosion. Nat Rev Mol Cell Biol 2010; 11: 700-714. 
75. Kroemer G, Levine B. Autophagic cell death: the story of a misnomer. Nat Rev Mol Cell Biol 2008; 9: 1004-1010.

76. Denton D, Nicolson S, Kumar S. Cell death by autophagy: facts and apparent artefacts. Cell Death Differ 2012; 19: 87-95.

77. Martinou I, Desagher S, Eskes R, Antonsson B, Andre E, Fakan S et al. The release of cytochrome $c$ from mitochondria during apoptosis of NGF-deprived sympathetic neurons is a reversible event. J Cell Biol 1999; 144: 883-889.

78. Vandenabeele P, Vanden Berghe T, Festjens N. Caspase inhibitors promote alternative cell death pathways. Sci STKE 2006; 2006: pe44.

79. Scheller C, Knoferle J, Ullrich A, Prottengeier J, Racek T, Sopper S et al. Caspase inhibition in apoptotic $T$ cells triggers necrotic cell death depending on the cell type and the proapoptotic stimulus. J Cell Biochem 2006; 97: 1350-1361.

80. Chautan M, Chazal G, Cecconi F, Gruss P, Golstein P. Interdigital cell death can occu through a necrotic and caspase-independent pathway. Curr Biol 1999; 9: 967-970.

81. Hirsch T, Marchetti P, Susin SA, Dallaporta B, Zamzami N, Marzo I et al. The apoptosisnecrosis paradox. Apoptogenic proteases activated after mitochondrial permeability transition determine the mode of cell death. Oncogene 1997; 15: 1573-1581.

82. Lockshin RA, Zakeri Z. Caspase-independent cell deaths. Curr Opin Cell Biol 2002; 14 727-733.

83. Mailleux AA, Overholtzer M, Schmelzle T, Bouillet P, Strasser A, Brugge JS. BIM regulates apoptosis during mammary ductal morphogenesis, and its absence reveals alternative cell death mechanisms. Dev Cell 2007; 12: 221-234.

84. Rashmi R, Pillai SG, Vijayalingam S, Ryerse J, Chinnadurai G. BH3-only protein BIK induces caspase-independent cell death with autophagic features in Bcl-2 null cells. Oncogene 2008; 27: 1366-1375

85. Okada M, Adachi S, Imai T, Watanabe K, Toyokuni SY, Ueno M et al. A novel mechanism for imatinib mesylate-induced cell death of BCR-ABL-positive human leukemic cells: caspase-independent, necrosis-like programmed cell death mediated by serine protease activity. Blood 2004; 103: 2299-2307.

86. Volbracht C, Leist M, Kolb SA, Nicotera P. Apoptosis in caspase-inhibited neurons. Mol Med 2001; 7: 36-48.

87. Miyazaki K, Yoshida H, Sasaki M, Hara H, Kimura G, Mak TW et al. Caspaseindependent cell death and mitochondrial disruptions observed in the Apaf1-deficient cells. J Biochem 2001; 129: 963-969.

88. Nagasaka A, Kawane K, Yoshida H, Nagata S. Apaf-1-independent programmed cell death in mouse development. Cell Death Differ 2010; 17: 931-941.

89. Oppenheim RW, Flavell RA, Vinsant S, Prevette D, Kuan CY, Rakic P. Programmed cell death of developing mammalian neurons after genetic deletion of caspases. $J$ Neurosci 2001; 21: 4752-4760.

90. Susin SA, Daugas E, Ravagnan L, Samejima K, Zamzami N, Loeffler M et al. Two distinct pathways leading to nuclear apoptosis. J Exp Med 2000; 192: 571-580.

91. Golstein P, Kroemer G. Redundant cell death mechanisms as relics and backups Cell Death Differ 2005; 12(Suppl 2): 1490-1496.

92. Caserta TM, Smith AN, Gultice AD, Reedy MA, Brown TL. Q-VD-OPh, a broad spectrum caspase inhibitor with potent antiapoptotic properties. Apoptosis 2003; 8: 345-352.

93. Zhu H, Fearnhead HO, Cohen GM. An ICE-like protease is a common mediator of apoptosis induced by diverse stimuli in human monocytic THP.1 cells. FEBS Lett 1995 374: 303-308

94. Chow SC, Weis M, Kass GE, Holmstrom TH, Eriksson JE, Orrenius S. Involvement of multiple proteases during Fas-mediated apoptosis in T lymphocytes. FEBS Lett 1995 364: 134-138.

95. Slee EA, Zhu H, Chow SC, MacFarlane M, Nicholson DW, Cohen GM. Benzyloxycarbonyl-Val-Ala-Asp (OMe) fluoromethylketone (Z-VAD.FMK) inhibits apoptosis by blocking the processing of CPP32. Biochem J 1996; 315(Part 1): 21-24.

96. Janicke RU, Sprengart ML, Wati MR, Porter AG. Caspase-3 is required for DNA fragmentation and morphological changes associated with apoptosis. J Biol Chem 1998 273: 9357-9360.

97. Coleman ML, Sahai EA, Yeo M, Bosch M, Dewar A, Olson MF. Membrane blebbing during apoptosis results from caspase-mediated activation of ROCK I. Nat Cell Biol 2001 3: 339-345.

98. Enzenmuller S, Gonzalez P, Karpel-Massler G, Debatin KM, Fulda S. GDC-0941 enhances the lysosomal compartment via TFEB and primes glioblastoma cells to Iysosomal membrane permeabilization and cell death. Cancer Lett 2013; 329: 27-36.

99. Mediavilla-Varela M, Pacheco FJ, Almaguel F, Perez J, Sahakian E, Daniels TR et al. Docetaxel-induced prostate cancer cell death involves concomitant activation of caspase and lysosomal pathways and is attenuated by LEDGF/p75. Mol Cancer 2009; 8: 68

100. Rebbaa A, Zheng X, Chou PM, Mirkin BL. Caspase inhibition switches doxorubicininduced apoptosis to senescence. Oncogene 2003; 22: 2805-2811.

101. Jouan-Lanhouet S, Arshad MI, Piquet-Pellorce C, Martin-Chouly C, Le Moigne-Muller G, Van Herreweghe $\mathrm{F}$ et al. TRAIL induces necroptosis involving RIPK1/RIPK3-dependent PARP-1 activation. Cell Death Differ 2012; 19: 2003-2014.

102. Vanden Berghe T, Kalai M, van Loo G, Declercq W, Vandenabeele P. Disruption of HSP90 function reverts tumor necrosis factor-induced necrosis to apoptosis. J Biol Chem 2003; 278: 5622-5629.

103. Vanlangenakker $N$, Bertrand MJ, Bogaert $P$, Vandenabeele $P$, Vanden Berghe $T$. TNF-induced necroptosis in L929 cells is tightly regulated by multiple TNFR1 complex and II members. Cell Death Dis 2011; 2: e230.
104. Remijsen Q, Goossens V, Grootjans S, Van den Haute C, Vanlangenakker N, Dondelinger Y et al. Depletion of RIPK3 or MLKL blocks TNF-driven necroptosis and switches towards a delayed RIPK1 kinase-dependent apoptosis. Cell Death Dis 2014; 5: e1004.

105. Kehe K, Raithel K, Kreppel H, Jochum M, Worek F, Thiermann H. Inhibition of poly(ADPribose) polymerase (PARP) influences the mode of sulfur mustard (SM)-induced cell death in HaCaT cells. Arch Toxicol 2008; 82: 461-470.

106. Pogrebniak A, Schemainda I, Pelka-Fleischer R, Nussler V, Hasmann M. Poly ADPribose polymerase (PARP) inhibitors transiently protect leukemia cells from alkylating agent induced cell death by three different effects. Eur J Med Res 2003; 8: 438-450.

107. Los M, Mozoluk M, Ferrari D, Stepczynska A, Stroh C, Renz A et al. Activation and caspase-mediated inhibition of PARP: a molecular switch between fibroblast necrosis and apoptosis in death receptor signaling. Mol Biol Cell 2002; 13: 978-988.

108. Gibson BA, Kraus WL. New insights into the molecular and cellular functions of poly (ADP-ribose) and PARPs. Nat Rev Mol Cell Biol 2012; 13: 411-424.

109. Michels J, Vitale I, Saparbaev M, Castedo M, Kroemer G. Predictive biomarkers for cancer therapy with PARP inhibitors. Oncogene 2013; 33: 3894-3907.

110. Ankarcrona M, Dypbukt JM, Bonfoco E, Zhivotovsky B, Orrenius S, Lipton SA et al. Glutamate-induced neuronal death: a succession of necrosis or apoptosis depending on mitochondrial function. Neuron 1995; 15: 961-973.

111. Leist M, Single B, Castoldi AF, Kuhnle S, Nicotera P. Intracellular adenosine triphosphate (ATP) concentration: a switch in the decision between apoptosis and necrosis. J Exp Med 1997; 185: 1481-1486.

112. Nicotera $P$, Leist M, Ferrando-May E. Intracellular ATP, a switch in the decision between apoptosis and necrosis. Toxicol Lett 1998; 102-103: 139-142.

113. Volbracht C, Leist M, Nicotera P. ATP controls neuronal apoptosis triggered by microtubule breakdown or potassium deprivation. Mol Med 1999; 5: 477-489.

114. Eguchi Y, Shimizu S, Tsujimoto Y. Intracellular ATP levels determine cell death fate by apoptosis or necrosis. Cancer Res 1997; 57: 1835-1840.

115. Nicotera P, Melino G. Regulation of the apoptosis-necrosis switch. Oncogene 2004; 23 : 2757-2765.

116. Saikumar P. Differential energy requirements for caspase activation and apoptosis FASEB J 2007; 21: A258

117. Liu X, Kim CN, Yang J, Jemmerson R, Wang X. Induction of apoptotic program in cell-free extracts: requirement for dATP and cytochrome c. Cell 1996; 86: 147-157.

118. Chandra D, Bratton SB, Person MD, Tian Y, Martin AG, Ayres M et al. Intracellular nucleotides act as critical prosurvival factors by binding to cytochrome $C$ and inhibiting apoptosome. Cell 2006; 125: 1333-1346.

119. Bratton SB, Salvesen GS. Regulation of the Apaf-1-caspase-9 apoptosome. J Cell Sci 2010; 123: 3209-3214.

120. Linkermann A, Green DR. Necroptosis. N Engl J Med 2014; 370: 455-465.

121. Vanden Berghe $T$, Linkermann A, Jouan-Lanhouet $S$, Walczak $H$, Vandenabeele $P$. Regulated necrosis: the expanding network of non-apoptotic cell death pathways. Nat Rev Mol Cell Biol 2014; 15: 135-147.

122. Laster SM, Wood JG, Gooding LR. Tumor necrosis factor can induce both apoptic and necrotic forms of cell lysis. J Immunol 1988; 141: 2629-2634.

123. Denecker G, Vercammen D, Steemans M, Vanden Berghe T, Brouckaert G, Van Loo G et al. Death receptor-induced apoptotic and necrotic cell death: differential role of caspases and mitochondria. Cell Death Differ 2001; 8: 829-840.

124. Vercammen D, Brouckaert G, Denecker G, Van de Craen M, Declercq W, Fiers W et al. Dual signaling of the Fas receptor: initiation of both apoptotic and necrotic cell death pathways. J Exp Med 1998; 188: 919-930.

125. Vercammen D, Beyaert R, Denecker G, Goossens V, Van Loo G, Declercq W et al. Inhibition of caspases increases the sensitivity of $L 929$ cells to necrosis mediated by tumor necrosis factor. J Exp Med 1998; 187: 1477-1485.

126. Vercammen D, Vandenabeele P, Beyaert R, Declercq W, Fiers W. Tumour necrosis factor-induced necrosis versus anti-Fas-induced apoptosis in L929 cells. Cytokine 1997; 9: $801-808$

127. Fiers W, Beyaert R, Boone E, Cornelis S, Declercq W, Decoster E et al. TNF-induced intracellular signaling leading to gene induction or to cytotoxicity by necrosis or by apoptosis. J Inflamm 1995; 47: 67-75.

128. Holler N, Zaru R, Micheau O, Thome M, Attinger A, Valitutti $S$ et al. Fas triggers an alternative, caspase-8-independent cell death pathway using the kinase RIP as effector molecule. Nat Immunol 2000; 1: 489-495.

129. Hitomi J, Christofferson DE, Ng A, Yao J, Degterev A, Xavier RJ et al. Identification of a molecular signaling network that regulates a cellular necrotic cell death pathway. Cell 2008; 135: 1311-1323.

130. Degterev A, Hitomi J, Germscheid M, Ch'en IL, Korkina O, Teng X et al. Identification of RIP1 kinase as a specific cellular target of necrostatins. Nat Chem Biol 2008; 4: 313-321.

131. Degterev A, Huang Z, Boyce M, Li Y, Jagtap P, Mizushima N et al. Chemical inhibitor of nonapoptotic cell death with therapeutic potential for ischemic brain injury. Nat Chem Biol 2005: 1: 112-119.

132. Schinzel AC, Takeuchi O, Huang Z, Fisher JK, Zhou Z, Rubens J et al. Cyclophilin D is a component of mitochondrial permeability transition and mediates neuronal cell death after focal cerebral ischemia. Proc Natl Acad Sci USA 2005; 102: 12005-12010.

133. Baines CP, Kaiser RA, Purcell NH, Blair NS, Osinska H, Hambleton MA et al. Loss of cyclophilin $\mathrm{D}$ reveals a critical role for mitochondrial permeability transition in cell death. Nature 2005; 434: 658-662. 
134. Nakagawa T, Shimizu S, Watanabe T, Yamaguchi O, Otsu K, Yamagata H et al. Cyclophilin D-dependent mitochondrial permeability transition regulates some necrotic but not apoptotic cell death. Nature 2005; 434: 652-658.

135. Basso E, Fante L, Fowlkes J, Petronilli V, Forte MA, Bernardi P. Properties of the permeability transition pore in mitochondria devoid of cyclophilin D. J Biol Chem 2005; 280: 18558-18561.

136. Mellen MA, de la Rosa EJ, Boya P. Autophagy is not universally required for phosphatidylserine exposure and apoptotic cell engulfment during neural development. Autophagy 2009; 5: 964-972

137. Mellen MA, de la Rosa EJ, Boya $P$. The autophagic machinery is necessary for removal of cell corpses from the developing retinal neuroepithelium. Cell Death Differ 2008; 15: 1279-1290.

138. Segawa K, Kurata S, Yanagihashi Y, Brummelkamp TR, Matsuda F, Nagata S. Caspasemediated cleavage of phospholipid flippase for apoptotic phosphatidylserine exposure. Science 2014; 344: 1164-1168.

139. Kenis H, Zandbergen HR, Hofstra L, Petrov AD, Dumont EA, Blankenberg FD et al. Annexin A5 uptake in ischemic myocardium: demonstration of reversible phosphatidylserine externalization and feasibility of radionuclide imaging. J Nucl Med 2010; 51: 259-267.

140. Martin SJ, Reutelingsperger CP, McGahon AJ, Rader JA, van Schie RC, LaFace DM et al. Early redistribution of plasma membrane phosphatidylserine is a general feature of apoptosis regardless of the initiating stimulus: inhibition by overexpression of $\mathrm{Bcl}-2$ and $\mathrm{Abl}$. $J$ Exp Med 1995; 182: 1545-1556.

141. Yang J, Liu X, Bhalla K, Kim CN, Ibrado AM, Cai J et al. Prevention of apoptosis by Bcl-2: release of cytochrome c from mitochondria blocked. Science 1997; 275: 1129-1132.

142. Li P, Nijhawan D, Budihardjo I, Srinivasula SM, Ahmad M, Alnemri ES et al. Cytochrome $c$ and dATP-dependent formation of Apaf-1/caspase-9 complex initiates an apoptotic protease cascade. Cell 1997; 91: 479-489.

143. Zou H, Henzel WJ, Liu X, Lutschg A, Wang X. Apaf-1, a human protein homologous to $C$. elegans CED-4, participates in cytochrome $c$-dependent activation of caspase-3. Cell 1997; 90: 405-413.

144. Ow YP, Green DR, Hao Z, Mak TW. Cytochrome $c$ : functions beyond respiration. Nat Rev Mol Cell Biol 2008; 9: 532-542.

145. Hardwick JM, Chen YB, Jonas EA. Multipolar functions of BCL-2 proteins link energetics to apoptosis. Trends Cell Biol 2012; 22: 318-328.

146. Danial NN. BCL-2 family proteins: critical checkpoints of apoptotic cell death. Clin Cancer Res 2007; 13: 7254-7263.

147. Rong Y, Distelhorst CW. Bcl-2 protein family members: versatile regulators of calcium signaling in cell survival and apoptosis. Annu Rev Physiol 2008; 70: 73-91.

148. Chipuk JE, Green DR. How do BCL-2 proteins induce mitochondrial outer membrane permeabilization? Trends Cell Biol 2008; 18: 157-164.

149. Kim H, Tu HC, Ren D, Takeuchi O, Jeffers JR, Zambetti GP et al. Stepwise activation of BAX and BAK by tBID, BIM, and PUMA initiates mitochondrial apoptosis. Mol Cell 2009; 36: 487-499.

150. Willis SN, Fletcher JI, Kaufmann T, van Delft MF, Chen L, Czabotar PE et al. Apoptosis initiated when BH3 ligands engage multiple Bcl-2 homologs, not Bax or Bak. Science 2007; 315: 856-859

151. Ren D, Tu HC, Kim H, Wang GX, Bean GR, Takeuchi O et al. BID, BIM, and PUMA are essential for activation of the BAX- and BAK-dependent cell death program. Science 2010; 330: 1390-1393.

152. Luo X, Budihardjo I, Zou H, Slaughter C, Wang X. Bid, a Bcl2 interacting protein, mediates cytochrome $\mathrm{c}$ release from mitochondria in response to activation of cell surface death receptors. Cell 1998; 94: 481-490.

153. Gross A, Yin XM, Wang K, Wei MC, Jockel J, Milliman $C$ et al. Caspase cleaved BID targets mitochondria and is required for cytochrome $c$ release, while $B C L-X L$ prevents this release but not tumor necrosis factor-R1/Fas death. J Biol Chem 1999; 274: 1156-1163.

154. Yin XM, Wang K, Gross A, Zhao Y, Zinkel S, Klocke B et al. Bid-deficient mice are resistant to Fas-induced hepatocellular apoptosis. Nature 1999; 400: 886-891.

155. Scaffidi C, Schmitz I, Zha J, Korsmeyer SJ, Krammer PH, Peter ME. Differential modulation of apoptosis sensitivity in CD95 type I and type II cells. J Biol Chem 1999; 274: 22532-22538.

156. Gonzalvez F, Schug ZT, Houtkooper RH, MacKenzie ED, Brooks DG, Wanders RJ et al. Cardiolipin provides an essential activating platform for caspase-8 on mitochondria. J Cell Biol 2008; 183: 681-696.

157. Zaltsman Y, Shachnai L, Yivgi-Ohana N, Schwarz M, Maryanovich M, Houtkooper RH et al. MTCH2/MIMP is a major facilitator of tBID recruitment to mitochondria. Nat Cell Biol 2010; 12: 553-562.

158. Jost PJ, Grabow S, Gray D, McKenzie MD, Nachbur U, Huang DC et al. XIAP discriminates between type I and type II FAS-induced apoptosis. Nature 2009; 460: $1035-1039$.

159. Albeck JG, Burke JM, Aldridge BB, Zhang M, Lauffenburger DA, Sorger PK. Quantitative analysis of pathways controlling extrinsic apoptosis in single cells. Mol Cell 2008; 30: $11-25$.

160. Schile AJ, Garcia-Fernandez M, Steller H. Regulation of apoptosis by XIAP ubiquitinligase activity. Genes Dev 2008; 22: 2256-2266.

161. Srinivasula SM, Hegde R, Saleh A, Datta P, Shiozaki E, Chai J et al. A conserved XIAP-interaction motif in caspase- 9 and Smac/DIABLO regulates caspase activity and apoptosis. Nature 2001; 410: 112-116.
162. Verhagen AM, Ekert PG, Pakusch M, Silke J, Connolly LM, Reid GE et al. Identification of DIABLO, a mammalian protein that promotes apoptosis by binding to and antagonizing IAP proteins. Cell 2000; 102: 43-53.

163. Du C, Fang M, Li Y, Li L, Wang X. Smac, a mitochondrial protein that promotes cytochrome $c$-dependent caspase activation by eliminating IAP inhibition. Cell 2000; 102: 33-42.

164. Van Loo G, Demol H, van Gurp M, Hoorelbeke B, Schotte P, Beyaert R et al. A matrixassisted laser desorption ionization post-source decay (MALDI-PSD) analysis of proteins released from isolated liver mitochondria treated with recombinant truncated Bid. Cell Death Differ 2002; 9: 301-308.

165. Galluzzi L, Kroemer G. Necroptosis: a specialized pathway of programmed necrosis. Cell 2008; 135: 1161-1163.

166. Zhang DW, Shao J, Lin J, Zhang N, Lu BJ, Lin SC et al. RIP3, an energy metabolism regulator that switches TNF-induced cell death from apoptosis to necrosis. Science 2009; 325: 332-336.

167. Cho YS, Challa S, Moquin D, Genga R, Ray TD, Guildford M et al. Phosphorylation-driven assembly of the RIP1-RIP3 complex regulates programmed necrosis and virus-induced inflammation. Cell 2009; 137: 1112-1123.

168. He S, Wang L, Miao L, Wang T, Du F, Zhao L et al. Receptor interacting protein kinase-3 determines cellular necrotic response to TNF-alpha. Cell 2009; 137: $1100-1111$.

169. Newton K, Dugger DL, Wickliffe KE, Kapoor N, de Almagro MC, Vucic D et al. Activity of protein kinase RIPK3 determines whether cells die by necroptosis or apoptosis. Science 2014; 343: 1357-1360.

170. Dondelinger Y, Declercq W, Montessuit S, Roelandt R, Goncalves A, Bruggeman I et al. MLKL compromises plasma membrane integrity by binding to phosphatidylinositol phosphates. Cell Rep 2014; 7: 971-981.

171. Wang H, Sun L, Su L, Rizo J, Liu L, Wang LF et al. Mixed lineage kinase domain-like protein MLKL causes necrotic membrane disruption upon phosphorylation by RIP3. Mol Cell 2014; 54: 133-146.

172. Moujalled DM, Cook WD, Murphy JM, Vaux DL. Necroptosis induced by RIPK3 requires MLKL but not Drp1. Cell Death Dis 2014; 5: e1086.

173. Galluzzi L, Kepp O, Kroemer G. MLKL regulates necrotic plasma membrane permeabilization. Cell Res 2014; 24: 139-140.

174. Chen X, Li W, Ren J, Huang D, He WT, Song Y et al. Translocation of mixed lineage kinase domain-like protein to plasma membrane leads to necrotic cell death. Cell Res 2014; 24: 105-121.

175. Cai Z, Jitkaew S, Zhao J, Chiang HC, Choksi S, Liu J et al. Plasma membrane translocation of trimerized MLKL protein is required for TNF-induced necroptosis. Nat Cell Biol 2014; 16: 55-65.

176. Murphy JM, Czabotar PE, Hildebrand JM, Lucet IS, Zhang JG, Alvarez-Diaz S et al. The pseudokinase MLKL mediates necroptosis via a molecular switch mechanism. Immunity 2013; 39: 443-453.

177. Wu J, Huang Z, Ren J, Zhang Z, He P, Li Y et al. Mlkl knockout mice demonstrate the indispensable role of Mlkl in necroptosis. Cell Res 2013; 23: 994-1006.

178. Zhao J, Jitkaew S, Cai Z, Choksi S, Li Q, Luo J et al. Mixed lineage kinase domain-like is a key receptor interacting protein 3 downstream component of TNF-induced necrosis Proc Natl Acad Sci USA 2012; 109: 5322-5327.

179. Sun L, Wang H, Wang Z, He S, Chen S, Liao D et al. Mixed lineage kinase domain-like protein mediates necrosis signaling downstream of RIP3 kinase. Cell 2012; 148 213-227.

180. Orozco S, Yatim N, Werner MR, Tran H, Gunja SY, Tait SW et al. RIPK1 both positively and negatively regulates RIPK3 oligomerization and necroptosis. Cell Death Differ 2014; 21: $1511-1521$.

181. Moujalled DM, Cook WD, Okamoto T, Murphy J, Lawlor KE, Vince JE et al. TNF can activate RIPK3 and cause programmed necrosis in the absence of RIPK1. Cell Death Dis 2013; 4: e465.

182. Kaiser WJ, Sridharan H, Huang C, Mandal P, Upton JW, Gough PJ et al. Toll-like receptor 3-mediated necrosis via TRIF, RIP3, and MLKL. J Biol Chem 2013; 288: 31268-31279.

183. Dillon CP, Weinlich R, Rodriguez DA, Cripps JG, Quarato G, Gurung $P$ et al RIPK1 blocks early postnatal lethality mediated by caspase-8 and RIPK3. Cell 2014; 157: $1189-1202$.

184. Tenev T, Bianchi K, Darding M, Broemer M, Langlais C, Wallberg $F$ et al. The Ripoptosome, a signaling platform that assembles in response to genotoxic stress and loss of IAPs. Mol Cell 2011; 43: 432-448.

185. Rickard JA, O'Donnell JA, Evans JM, Lalaoui N, Poh AR, Rogers T et al. RIPK1 regulates RIPK3-MLKL-driven systemic inflammation and emergency hematopoiesis. Cell 2014; 157: $1175-1188$.

186. Kaiser WJ, Daley-Bauer LP, Thapa RJ, Mandal P, Berger SB, Huang C et al. RIP1 suppresses innate immune necrotic as well as apoptotic cell death during mammalian parturition. Proc Natl Acad Sci USA 2014; 111: 7753-7758.

187. Upton JW, Kaiser WJ, Mocarski ES. DAI/ZBP1/DLM-1 complexes with RIP3 to mediate virus-induced programmed necrosis that is targeted by murine cytomegalovirus vIRA Cell Host Microbe 2012; 11: 290-297.

188. Basit F, Cristofanon S, Fulda S. Obatoclax (GX15-070) triggers necroptosis by promoting the assembly of the necrosome on autophagosomal membranes. Cell Death Differ 2013; 20: $1161-1173$. 
189. Tait SW, Oberst A, Quarato G, Milasta S, Haller M, Wang R et al. Widespread mitochondrial depletion via mitophagy does not compromise necroptosis. Cell Rep 2013; 5: 878-885.

190. Wang Z, Jiang $H$, Chen S, Du F, Wang X. The mitochondrial phosphatase PGAM5 functions at the convergence point of multiple necrotic death pathways. Cell 2012; 148 228-243.

191. Vince JE, Wong WW, Gentle I, Lawlor KE, Allam R, O'Reilly L et al. Inhibitor of apoptosis proteins limit RIP3 kinase-dependent interleukin-1 activation. Immunity 2012; 36: 215-227.

192. Dondelinger Y, Aguileta MA, Goossens V, Dubuisson C, Grootjans S, Dejardin E et al. RIPK3 contributes to TNFR1-mediated RIPK1 kinase-dependent apoptosis in conditions of CIAP1/2 depletion or TAK1 kinase inhibition. Cell Death Differ 2013; 20: 1381-1392.

193. Vanlangenakker N, Vanden Berghe T, Bogaert P, Laukens B, Zobel K, Deshayes K et al. CIAP1 and TAK1 protect cells from TNF-induced necrosis by preventing RIP1/RIP3 dependent reactive oxygen species production. Cell Death Differ 2011; 18: 656-665.

194. O'Donnell MA, Perez-Jimenez E, Oberst A, Ng A, Massoumi R, Xavier R et al. Caspase 8 inhibits programmed necrosis by processing CYLD. Nat Cell Biol 2011; 13: 1437-1442.

195. Green DR, Oberst A, Dillon CP, Weinlich R, Salvesen GS. RIPK-dependent necrosis and its regulation by caspases: a mystery in five acts. Mol Cell 2011; 44: 9-16.

196. Weinlich R, Dillon CP, Green DR. Ripped to death. Trends Cell Biol 2011; 21: 630-637.

197. Oberst A, Dillon CP, Weinlich R, McCormick LL, Fitzgerald P, Pop C et al. Catalytic activity of the caspase-8-FLIP(L) complex inhibits RIPK3-dependent necrosis. Nature 2011; 471 363-367.

198. Wajant $\mathrm{H}$. The Fas signaling pathway: more than a paradigm. Science 2002; 296 1635-1636.

199. Chinnaiyan AM, Tepper CG, Seldin MF, O'Rourke K, Kischkel FC, Hellbardt S et al. FADD/MORT1 is a common mediator of CD95 (Fas/APO-1) and tumor necrosis factor receptor-induced apoptosis. J Biol Chem 1996; 271: 4961-4965.

200. Chinnaiyan AM, O'Rourke K, Tewari M, Dixit VM. FADD, a novel death domain-containing protein, interacts with the death domain of Fas and initiates apoptosis. Cell 1995; 81 $505-512$.

201. Irmler M, Thome M, Hahne M, Schneider P, Hofmann K, Steiner V et al. Inhibition of death receptor signals by cellular FLIP. Nature 1997; 388: 190-195.

202. Muzio M, Chinnaiyan AM, Kischkel FC, O'Rourke K, Shevchenko A, Ni J et al. FLICE, a novel FADD-homologous ICE/CED-3-like protease, is recruited to the CD95 (Fas/APO-1) death-inducing signaling complex. Cell 1996; 85: 817-827.

203. Kischkel FC, Hellbardt S, Behrmann I, Germer M, Pawlita M, Krammer PH et al. Cytotoxicity-dependent APO-1 (Fas/CD95)-associated proteins form a death-inducing signaling complex (DISC) with the receptor. EMBO J 1995; 14: 5579-5588.

204. Vandenabeele $P$, Melino $G$. The flick of a switch: which death program to choose? Cell Death Differ 2012; 19: 1093-1095.

205. Tait SW, Ichim G, Green DR. Die another way - non-apoptotic mechanisms of cell death J Cell Sci 2014; 127: 2135-2144

206. Cook WD, Moujalled DM, Ralph TJ, Lock P, Young SN, Murphy JM et al. RIPK1- and RIPK3-induced cell death mode is determined by target availability. Cell Death Diffe 2014; 21: 1600-1612.

207. Morioka S, Broglie P, Omori E, Ikeda Y, Takaesu G, Matsumoto K et al. TAK1 kinase switches cell fate from apoptosis to necrosis following TNF stimulation. J Cell Biol 2014 204: 607-623

208. Pietrocola F, Izzo V, Niso-Santano M, Vacchelli E, Galluzzi L, Maiuri MC et al. Regulation of autophagy by stress-responsive transcription factors. Semin Cancer Biol 2013; 23: 310-322.

209. Shin JH, Min SH, Kim SJ, Kim YI, Park J, Lee HK et al. TAK1 regulates autophagic cel death by suppressing the phosphorylation of p70 S6 kinase 1. Sci Rep 2013; 3: 1561.

210. Criollo A, Niso-Santano M, Malik SA, Michaud M, Morselli E, Marino G et al. Inhibition of autophagy by TAB2 and TAB3. EMBO J 2011; 30: 4908-4920.

211. Ben-Neriah Y, Karin M. Inflammation meets cancer, with NF-kappaB as the matchmaker. Nat Immunol 2011; 12: 715-723.

212. Vallabhapurapu S, Karin M. Regulation and function of NF-kappaB transcription factors in the immune system. Annu Rev Immunol 2009; 27: 693-733.

213. Bertrand MJ, Milutinovic S, Dickson KM, Ho WC, Boudreault A, Durkin J et al. clAP1 and CIAP2 facilitate cancer cell survival by functioning as E3 ligases that promote RIP1 ubiquitination. Mol Cell 2008; 30: 689-700.

214. Kroemer G, Galluzzi L, Brenner C. Mitochondrial membrane permeabilization in cell death. Physiol Rev 2007; 87: 99-163.

215. Galluzzi L, Kroemer G. Mitochondrial apoptosis without VDAC. Nat Cell Biol 2007; 9 : 487-489.

216. Baines CP, Kaiser RA, Sheiko T, Craigen WJ, Molkentin JD. Voltage-dependent anion channels are dispensable for mitochondrial-dependent cell death. Nat Cell Biol 2007; 9 550-555.

217. Vaseva AV, Marchenko ND, Ji K, Tsirka SE, Holzmann S, Moll UM. P53 opens the mitochondrial permeability transition pore to trigger necrosis. Cell 2012; 149: 1536-1548.

218. Verrier F, Mignotte B, Jan G, Brenner C. Study of PTPC composition during apoptosis for identification of viral protein target. Ann NY Acad Sci 2003; 1010: 126-142.

219. Brenner C, Moulin M. Physiological roles of the permeability transition pore. Circ Res 2012; 111: 1237-1247.

220. Brenner C, Grimm S. The permeability transition pore complex in cancer cell death Oncogene 2006; 25: 4744-4756.
221. Lemasters JJ, Theruvath TP, Zhong Z, Nieminen AL. Mitochondrial calcium and the permeability transition in cell death. Biochim Biophys Acta 2009; 1787: 1395-1401.

222. Tait SW, Green DR. Mitochondrial regulation of cell death. Cold Spring Harb Perspect Bio 2013; 5: doi:10.1101/cshperspect.a008706.

223. Tait SW, Green DR. Mitochondria and cell signalling. J Cell Sci 2012; 125: 807-815.

224. Tait SW, Green DR. Mitochondria and cell death: outer membrane permeabilization and beyond. Nat Rev Mol Cell Biol 2010; 11: 621-632.

225. Tait SW, Parsons MJ, Llambi F, Bouchier-Hayes L, Connell S, Munoz-Pinedo C et al. Resistance to caspase-independent cell death requires persistence of intact mitochondria. Dev Cell 2010; 18: 802-813.

226. Li Y, Johnson N, Capano M, Edwards M, Crompton M. Cyclophilin-D promotes the mitochondrial permeability transition but has opposite effects on apoptosis and necrosis. Biochem J 2004; 383: 101-109.

227. Kroemer G, Martin SJ. Caspase-independent cell death. Nat Med 2005; 11: 725-730.

228. Dam AD, Mitchell AS, Quadrilatero J. Induction of mitochondrial biogenesis protects against caspase-dependent and caspase-independent apoptosis in L6 myoblasts. Biochim Biophys Acta 2013; 1833: 3426-3435.

229. Bonora M, Wieckowski MR, Chinopoulos C, Kepp O, Kroemer G, Galluzzi L et al. Molecular mechanisms of cell death: central implication of ATP synthase in mitochondrial permeability transition. Oncogene 2014; e-pub ahead of print 14 April 2014; doi:10.1038/ onc.2014.96.

230. Zhivotovsky B, Galluzzi L, Kepp O, Kroemer G. Adenine nucleotide translocase: a component of the phylogenetically conserved cell death machinery. Cell Death Differ 2009; 16: 1419-1425.

231. Giorgio V, von Stockum S, Antoniel M, Fabbro A, Fogolari F, Forte M et al. Dimers of mitochondrial ATP synthase form the permeability transition pore. Proc Natl Acad Sci USA 2013; 110: 5887-5892

232. Bonora M, Bononi A, De Marchi E, Giorgi C, Lebiedzinska M, Marchi S et al. Role of the C subunit of the FO ATP synthase in mitochondrial permeability transition. Cell Cycle 2013; 12: $674-683$

233. Campanella M, Parker N, Tan $\mathrm{CH}$, Hall AM, Duchen MR. IF(1): setting the pace of the F(1)F(0)-ATP synthase. Trends Biochem Sci 2009; 34: 343-350.

234. Alavian KN, Beutner G, Lazrove E, Sacchetti S, Park HA, Licznerski $P$ et al. An uncoupling channel within the c-subunit ring of the F1FO ATP synthase is the mitochondrial permeability transition pore. Proc Natl Acad Sci USA 2014; 111: 10580-10585.

235. Pan X, Liu J, Nguyen T, Liu C, Sun J, Teng Y et al. The physiological role of mitochondrial calcium revealed by mice lacking the mitochondrial calcium uniporter. Nat Cell Biol 2013; 15: 1464-1472.

236. Murphy E, Pan X, Nguyen T, Liu J, Holmstrom KM, Finkel T. Unresolved questions from the analysis of mice lacking MCU expression. Biochem Biophys Res Commun 2014; 449: 384-385.

237. Fatokun AA, Dawson VL, Dawson TM. Parthanatos: mitochondrial-linked mechanisms and therapeutic opportunities. Br J Pharmacol 2014; 171: 2000-2016.

238. Wang Y, Kim NS, Haince JF, Kang HC, David KK, Andrabi SA et al. Poly(ADP-ribose) (PAR) binding to apoptosis-inducing factor is critical for PAR polymerase-1-dependent cell death (parthanatos). Sci Signal 2011; 4: ra20.

239. Yu SW, Andrabi SA, Wang H, Kim NS, Poirier GG, Dawson TM et al. Apoptosis-inducing factor mediates poly(ADP-ribose) (PAR) polymer-induced cell death. Proc Natl Acad Sci USA 2006; 103: 18314-18319.

240. Yu SW, Wang H, Poitras MF, Coombs C, Bowers WJ, Federoff HJ et al. Mediation of poly(ADP-ribose) polymerase-1-dependent cell death by apoptosis-inducing factor. Science 2002; 297: 259-263.

241. Sosna J, Voigt S, Mathieu S, Lange A, Thon L, Davarnia P et al. TNF-induced necroptosis and PARP-1-mediated necrosis represent distinct routes to programmed necrotic cell death. Cell Mol Life Sci 2014; 71: 331-348.

242. Park EJ, Min KJ, Lee TJ, Yoo YH, Kim YS, Kwon TK beta-Lapachone induces programmed necrosis through the RIP1-PARP-AIF-dependent pathway in human hepatocellular carcinoma SK-Hep1 cells. Cell Death Dis 2014; 5: e1230.

243. Vanlangenakker $N$, Vanden Berghe $T$, Vandenabeele $P$. Many stimuli pull the necrotic trigger, an overview. Cell Death Differ 2012; 19: 75-86.

244. Skouta R, Dixon SJ, Wang J, Dunn DE, Orman M, Shimada K et al. Ferrostatins inhibit oxidative lipid damage and cell death in diverse disease models. J Am Chem Soc 2014; 136: $4551-4556$.

245. Yang WS, SriRamaratnam R, Welsch ME, Shimada K, Skouta R, Viswanathan VS et al. Regulation of ferroptotic cancer cell death by GPX4. Cell 2014; 156: 317-331.

246. Dixon SJ, Stockwell BR. The role of iron and reactive oxygen species in cell death. Nat Chem Biol 2014; 10: 9-17.

247. Dixon SJ, Lemberg KM, Lamprecht MR, Skouta R, Zaitsev EM, Gleason CE et al. Ferroptosis: an iron-dependent form of nonapoptotic cell death. Cell 2012; 149: 1060-1072.

248. Dolma S, Lessnick SL, Hahn WC, Stockwell BR. Identification of genotype-selective antitumor agents using synthetic lethal chemical screening in engineered human tumor cells. Cancer Cell 2003; 3: 285-296.

249. Tan S, Schubert D, Maher P. Oxytosis: a novel form of programmed cell death. Curr Top Med Chem 2001; 1: 497-506. 
250. Noch E, Khalili K. Molecular mechanisms of necrosis in glioblastoma: the role of glutamate excitotoxicity. Cancer Biol Ther 2009; 8: 1791-1797.

251. Arundine M, Tymianski M. Molecular mechanisms of calcium-dependent neurodegeneration in excitotoxicity. Cell Calcium 2003; 34: 325-337.

252. Marino G, Niso-Santano M, Baehrecke EH, Kroemer G. Self-consumption: the interplay of autophagy and apoptosis. Nat Rev Mol Cell Biol 2014; 15: 81-94.

253. Grander D, Kharaziha P, Laane E, Pokrovskaja K, Panaretakis T. Autophagy as the main means of cytotoxicity by glucocorticoids in hematological malignancies. Autophagy 2009; 5: 1198-1200.

254. Laane E, Tamm KP, Buentke E, Ito K, Kharaziha P, Oscarsson J et al. Cell death induced by dexamethasone in lymphoid leukemia is mediated through initiation of autophagy. Cell Death Differ 2009; 16: 1018-1029.

255. Liu Y, Shoji-Kawata S, Sumpter Jr RM, Wei $Y$, Ginet V, Zhang $L$ et al. Autosis is a $\mathrm{Na}+, \mathrm{K}+-$ ATPase-regulated form of cell death triggered by autophagy-inducing peptides, starvation, and hypoxia-ischemia. Proc Natl Acad Sci USA 2013; 110: 20364-20371.

256. Varma H, Gangadhar NM, Letso RR, Wolpaw AJ, Sriramaratnam R, Stockwell BR. Identification of a small molecule that induces ATG5-and-cathepsin-I-dependent cell death and modulates polyglutamine toxicity. Exp Cell Res 2013; 319: 1759-1773.

257. Elgendy M, Sheridan C, Brumatti G, Martin SJ. Oncogenic Ras-induced expression of Noxa and Beclin-1 promotes autophagic cell death and limits clonogenic survival. Mol Cell 2011; 42: 23-35.

258. Nihira K, Miki Y, Ono K, Suzuki T, Sasano H. An inhibition of p62/SQSTM1 caused autophagic cell death of several human carcinoma cells. Cancer Sci 2014; 105: 568-575.

259. Chen SY, Chiu LY, Maa MC, Wang JS, Chien CL, Lin WW. zVAD-induced autophagic cell death requires $c$-Src-dependent ERK and JNK activation and reactive oxygen species generation. Autophagy 2011; 7: 217-228.

260. Munoz-Pinedo C, Martin SJ. Autosis: a new addition to the cell death tower of babel. Cell Death Dis 2014; 5: e1319.

261. Prabhakaran K, Li L, Borowitz JL, Isom GE. Caspase inhibition switches the mode of cell death induced by cyanide by enhancing reactive oxygen species generation and PARP-1 activation. Toxicol Appl Pharmacol 2004; 195: 194-202.

262. McCarthy NJ, Whyte MK, Gilbert CS, Evan GI. Inhibition of Ced-3/ICE-related proteases does not prevent cell death induced by oncogenes, DNA damage, or the Bcl-2 homologue Bak. J Cell Biol 1997; 136: 215-227.

263. Steinhart L, Belz K, Fulda S. Smac mimetic and demethylating agents synergistically trigger cell death in acute myeloid leukemia cells and overcome apoptosis resistance by inducing necroptosis. Cell Death Dis 2013; 4: e802.

264. Dunai ZA, Imre G, Barna G, Korcsmaros T, Petak I, Bauer PI et al. Staurosporine induces necroptotic cell death under caspase-compromised conditions in U937 cells. PLoS One 2012; 7: e41945.

265. Minina EA, Filonova LH, Fukada K, Savenkov El, Gogvadze V, Clapham D et al. Autophagy and metacaspase determine the mode of cell death in plants. J Cell Biol 2013 203: 917-927.

266. Chen WW, Yu H, Fan HB, Zhang CC, Zhang M, Zhang C et al. RIP1 mediates the protection of geldanamycin on neuronal injury induced by oxygen-glucose deprivation combined with zVAD in primary cortical neurons. J Neurochem 2012; 120: 70-77.

267. Han W, Xie J, Fang Y, Wang Z, Pan H. Nec-1 enhances shikonin-induced apoptosis in leukemia cells by inhibition of RIP-1 and ERK1/2. Int J Mol Sci 2012; 13: 7212-7225.

268. Luo JL, Kamata H, Karin M. IKK/NF-kappaB signaling: balancing life and death - a new approach to cancer therapy. J Clin Invest 2005; 115: 2625-2632.

269. Hughes MA, Harper N, Butterworth M, Cain K, Cohen GM, MacFarlane M. Reconstitution of the death-inducing signaling complex reveals a substrate switch that determines CD95-mediated death or survival. Mol Cell 2009; 35: 265-279.

270. Ide T, Brown-Endres L, Chu K, Ongusaha PP, Ohtsuka T, El-Deiry WS et al. GAMT, a p53-inducible modulator of apoptosis, is critical for the adaptive response to nutrient stress. Mol Cell 2009; 36: 379-392.

271. Khalil H, Bertrand MJ, Vandenabeele P, Widmann C. Caspase-3 and RasGAP: a stress-sensing survival/demise switch. Trends Cell Biol 2014; 24: 83-89.

272. Nikoletopoulou V, Markaki M, Palikaras K, Tavernarakis N. Crosstalk between apoptosis, necrosis and autophagy. Biochim Biophys Acta 2013; 1833: 3448-3459.

273. Albeck JG, Burke JM, Spencer SL, Lauffenburger DA, Sorger PK. Modeling a snap-action, variable-delay switch controlling extrinsic cell death. PLOS Biol 2008; 6 : 2831-2852.

274. Linkermann A, Brasen JH, Darding M, Jin MK, Sanz AB, Heller JO et al. Two independent pathways of regulated necrosis mediate ischemia-reperfusion injury. Proc Natl $\mathrm{Acad} S \mathrm{SC}$ USA 2013; 110: 12024-12029.

275. Linkermann A, Brasen JH, De Zen F, Weinlich R, Schwendener RA, Green DR et al. Dichotomy between RIP1- and RIP3-mediated necroptosis in tumor necrosis factor-alpha-induced shock. Mol Med 2012; 18: 577-586.

276. Duprez L, Takahashi N, Van Hauwermeiren F, Vandendriessche B, Goossens V, Vanden Berghe $T$ et al. RIP kinase-dependent necrosis drives lethal systemic inflammatory response syndrome. Immunity 2011; 35: 908-918.

277. Trichonas G, Murakami Y, Thanos A, Morizane Y, Kayama M, Debouck CM et al. Receptor interacting protein kinases mediate retinal detachment-induced photoreceptor necrosis and compensate for inhibition of apoptosis. Proc Natl Acad Sci USA 2010; 107: 21695-21700.
278. Kim SJ, Li J. Caspase blockade induces RIP3-mediated programmed necrosis in Toll-like receptor-activated microglia. Cell Death Dis 2013; 4: e716.

279. Yoshida H, Kong YY, Yoshida R, Elia AJ, Hakem A, Hakem R et al. Apaf1 is required for mitochondrial pathways of apoptosis and brain development. Cell 1998; 94: 739-750.

280. Cecconi F, Alvarez-Bolado G, Meyer BI, Roth KA, Gruss P. Apaf1 (CED-4 homolog) regulates programmed cell death in mammalian development. Cell 1998; 94: 727-737.

281. Hakem R, Hakem A, Duncan GS, Henderson JT, Woo M, Soengas MS et al. Differential requirement for caspase 9 in apoptotic pathways in vivo. Cell 1998; 94: 339-352.

282. Kuida K, Haydar TF, Kuan CY, Gu Y, Taya C, Karasuyama H et al. Reduced apoptosis and cytochrome $c$-mediated caspase activation in mice lacking caspase 9. Cell 1998; 94: 325-337.

283. Woo M, Hakem R, Soengas MS, Duncan GS, Shahinian A, Kagi D et al. Essentia contribution of caspase 3/CPP32 to apoptosis and its associated nuclear changes. Genes Dev 1998; 12: 806-819.

284. Kuida K, Zheng TS, Na S, Kuan C, Yang D, Karasuyama H et al. Decreased apoptosis in the brain and premature lethality in CPP32-deficient mice. Nature 1996; 384: 368-372.

285. Li J, Yuan J. Caspases in apoptosis and beyond. Oncogene 2008; 27: 6194-6206.

286. Degterev A, Boyce M, Yuan J. A decade of caspases. Oncogene 2003; 22: 8543-8567.

287. Honarpour N, Du C, Richardson JA, Hammer RE, Wang X, Herz J. Adult Apaf-1-deficient mice exhibit male infertility. Dev Biol 2000; 218: 248-258.

288. Wei MC, Zong WX, Cheng EH, Lindsten T, Panoutsakopoulou V, Ross AJ et al. Proapoptotic $B A X$ and BAK: a requisite gateway to mitochondrial dysfunction and death. Science 2001; 292: 727-730.

289. Puthalakath $\mathrm{H}$, Strasser $\mathrm{A}$. Keeping killers on a tight leash: transcriptional and posttranslational control of the pro-apoptotic activity of $\mathrm{BH}$-only proteins. Cell Death Differ 2002; 9: 505-512.

290. Puthalakath H, Villunger A, O'Reilly LA, Beaumont JG, Coultas L, Cheney RE et al. Bmf: a proapoptotic $\mathrm{BH} 3$-only protein regulated by interaction with the myosin $\mathrm{V}$ actin motor complex, activated by anoikis. Science 2001; 293: 1829-1832.

291. Bouillet P, Purton JF, Godfrey DI, Zhang LC, Coultas L, Puthalakath $\mathrm{H}$ et al. BH3-only BCl-2 family member Bim is required for apoptosis of autoreactive thymocytes. Nature 2002; 415: 922-926.

292. Lindsten T, Ross AJ, King A, Zong WX, Rathmell JC, Shiels HA et al. The combined functions of proapoptotic Bcl-2 family members bak and bax are essential for normal development of multiple tissues. Mol Cell 2000; 6: 1389-1399.

293. Labi V, Woess C, Tuzlak S, Erlacher M, Bouillet P, Strasser A et al. Deregulated cell death and lymphocyte homeostasis cause premature lethality in mice lacking the $\mathrm{BH} 3-$ only proteins Bim and Bmf. Blood 2014; 123: 2652-2662.

294. O'Brien RJ, Wong PC. Amyloid precursor protein processing and Alzheimer's disease. Annu Rev Neurosci 2011; 34: 185-204.

295. D'Amelio M, Sheng M, Cecconi F. Caspase-3 in the central nervous system: beyond apoptosis. Trends Neurosci 2012; 35: 700-709.

296. Bredesen DE, Rao RV, Mehlen P. Cell death in the nervous system. Nature 2006; 443 796-802.

297. Nakamura T, Wang L, Wong CC, Scott FL, Eckelman BP, Han X et al. Transnitrosylation of XIAP regulates caspase-dependent neuronal cell death. Mol Cell 2010; 39: 184-195.

298. Burguillos MA, Deierborg T, Kavanagh E, Persson A, Haiji N, Garcia-Quintanilla A et al. Caspase signalling controls microglia activation and neurotoxicity. Nature 2011; 472: 319-324.

299. Barut S, Unlu YA, Karaoglan A, Tuncdemir M, Dagistanli FK, Ozturk M et al. The neuroprotective effects of z-DEVD.fmk, a caspase-3 inhibitor, on traumatic spinal cord injury in rats. Surg Neurol 2005; 64: 213-220; discussion 220.

300. Knoblach SM, Alroy DA, Nikolaeva M, Cernak I, Stoica BA, Faden Al. Caspase inhibitor z-DEVD-fmk attenuates calpain and necrotic cell death in vitro and after traumatic brain injury. J Cereb Blood Flow Metab 2004; 24: 1119-1132.

301. Renolleau S, Fau S, Goyenvalle C, Joly LM, Chauvier D, Jacotot E et al. Specific caspase inhibitor Q-VD-OPh prevents neonatal stroke in P7 rat: a role for gender. J Neurochem 2007; 100: 1062-1071.

302. Endres M, Namura S, Shimizu-Sasamata M, Waeber C, Zhang L, Gomez-Isla T et al. Attenuation of delayed neuronal death after mild focal ischemia in mice by inhibition of the caspase family. J Cereb Blood Flow Metab 1998; 18: 238-247.

303. Han BH, Xu D, Choi J, Han Y, Xanthoudakis S, Roy S et al. Selective, reversible caspase3 inhibitor is neuroprotective and reveals distinct pathways of cell death after neonatal hypoxic-ischemic brain injury. J Biol Chem 2002; 277: 30128-30136.

304. Han W, Sun Y, Wang X, Zhu C, Blomgren K. Delayed, long-term administration of the caspase inhibitor Q-VD-OPh reduced brain injury induced by neonatal hypoxia-ischemia. Dev Neurosci 2014; 36: 64-72.

305. Wolf BB, Goldstein JC, Stennicke HR, Beere H, Amarante-Mendes GP, Salvesen GS et al Calpain functions in a caspase-independent manner to promote apoptosis-like events during platelet activation. Blood 1999; 94: 1683-1692.

306. Schotte P, Declercq W, Van Huffel S, Vandenabeele P, Beyaert R. Non-specific effects of methyl ketone peptide inhibitors of caspases. FEBS Lett 1999; 442: 117-121.

307. Garrido C, Galluzzi L, Brunet M, Puig PE, Didelot C, Kroemer G. Mechanisms of cytochrome $c$ release from mitochondria. Cell Death Differ 2006; 13: 1423-1433.

308. Mondragon L, Galluzzi L, Mouhamad S, Orzaez M, Vicencio JM, Vitale I et al. A chemical inhibitor of Apaf-1 exerts mitochondrioprotective functions and interferes with the intra-S-phase DNA damage checkpoint. Apoptosis 2009; 14: 182-190.

309. Slee EA, Keogh SA, Martin SJ. Cleavage of BID during cytotoxic drug and UV radiationinduced apoptosis occurs downstream of the point of $\mathrm{Bcl}-2$ action and is catalysed by 
caspase-3: a potential feedback loop for amplification of apoptosis-associated mitochondrial cytochrome c release. Cell Death Differ 2000; 7: 556-565.

310. Lakhani SA, Masud A, Kuida K, Porter Jr GA, Booth CJ, Mehal WZ et al. Caspases 3 and 7: key mediators of mitochondrial events of apoptosis. Science 2006; 311: 847-851.

311. Krysko O, Love Aaes T, Bachert C, Vandenabeele P, Krysko DV. Many faces of DAMPs in cancer therapy. Cell Death Dis 2013; 4: e631.

312. Kaczmarek A, Vandenabeele P, Krysko DV. Necroptosis: the release of damageassociated molecular patterns and its physiological relevance. Immunity 2013; 38: 209-223.

313. Hou W, Zhang Q, Yan Z, Chen R, Zeh lii HJ, Kang R et al. Strange attractors: DAMPs and autophagy link tumor cell death and immunity. Cell Death Dis 2013; 4: e966.

314. Knight KR, Zhang B, Morrison WA, Stewart AG. Ischaemia-reperfusion injury in mouse skeletal muscle is reduced by Nomega-nitro-L-arginine methyl ester and dexamethasone. Eur J Pharmacol 1997; 332: 273-278

315. Kumar S, Allen DA, Kieswich JE, Patel NS, Harwood S, Mazzon E et al. Dexamethasone ameliorates renal ischemia-reperfusion injury. J Am Soc Nephrol 2009; 20: 2412-2425.

316. Zhang W, Xing J, Liu D, Gan X, Gao W, Hei Z. Dexamethasone pretreatment alleviates intestinal ischemia-reperfusion injury. J Surg Res 2013; 185: 851-860.

317. Kraft P, Gob E, Schuhmann MK, Gobel K, Deppermann C, Thielmann I et al. FTY720 ameliorates acute ischemic stroke in mice by reducing thrombo-inflammation but not by direct neuroprotection. Stroke 2013; 44: 3202-3210.

318. Pacher P, Szabo C. Role of poly(ADP-ribose) polymerase 1 (PARP-1) in cardiovascular diseases: the therapeutic potential of PARP inhibitors. Cardiovasc Drug Rev 2007; 25 235-260.

319. del Moral RM, Gomez-Morales M, Hernandez-Cortes P, Aguilar D, Caballero T Aneiros-Fernandez $\mathrm{J}$ et al. PARP inhibition attenuates histopathological lesion in ischemia/reperfusion renal mouse model after cold prolonged ischemia. Scientific World $J$ 2013; 2013: 486574.

320. Li X, Klaus JA, Zhang J, Xu Z, Kibler KK, Andrabi SA et al. Contributions of poly (ADP-ribose) polymerase-1 and -2 to nuclear translocation of apoptosis-inducing factor and injury from focal cerebral ischemia. J Neurochem 2010; 113: 1012-1022.

321. Curtin NJ, Szabo C. Therapeutic applications of PARP inhibitors: anticancer therapy and beyond. Mol Aspects Med 2013; 34: 1217-1256

322. Vanden Berghe T, Vanlangenakker N, Parthoens E, Deckers W, Devos M, Festjens N et al. Necroptosis, necrosis and secondary necrosis converge on similar cellular disintegration features. Cell Death Differ 2010; 17: 922-930.

323. Tang HL, Tang HM, Mak KH, Hu S, Wang SS, Wong KM et al. Cell survival, DNA damage, and oncogenic transformation after a transient and reversible apoptotic response. Mol Biol Cell 2012; 23: 2240-2252.

324. Tang HL, Tang HM, Hardwick JM, Fung MC. Strategies for tracking anastasis, a cell survival phenomenon that reverses apoptosis. J Vis Exp 2014; 2014: e51964.

325. Zhu D, Cardenas ME, Heitman J. Calcineurin mutants render T lymphocytes resistant to cyclosporin A. Mol Pharmacol 1996; 50: 506-511.
326. Fruman DA, Klee CB, Bierer BE, Burakoff $\mathrm{SJ}$. Calcineurin phosphatase activity in $T$ lymphocytes is inhibited by FK 506 and cyclosporin A. Proc Natl Acad Sci USA 1992; 89: 3686-3690.

327. Gomes LC, Di Benedetto G, Scorrano L. During autophagy mitochondria elongate, are spared from degradation and sustain cell viability. Nat Cell Biol 2011; 13: 589-598.

328. Brookes PS, Yoon Y, Robotham JL, Anders MW, Sheu SS. Calcium, ATP and ROS: a mitochondrial love-hate triangle. Am J Physiol Cell Physiol 2004; 287: C817-C833.

329. Zimmermann KC, Ricci JE, Droin NM, Green DR. The role of ARK in stress-induced apoptosis in Drosophila cells. J Cell Biol 2002; 156: 1077-1087.

330. Kanuka H, Sawamoto K, Inohara N, Matsuno K, Okano H, Miura M. Control of the cell death pathway by Dapaf-1, a Drosophila Apaf-1/CED-4-related caspase activator. Mol Cell 1999; 4: 757-769.

331. Xue D, Horvitz HR. Inhibition of the Caenorhabditis elegans cell-death protease CED-3 by a CED-3 cleavage site in baculovirus p35 protein. Nature 1995; 377: 248-251.

332. Daish TJ, Mills K, Kumar S. Drosophila caspase DRONC is required for specific developmental cell death pathways and stress-induced apoptosis. Dev Cell 2004; 7 : 909-915.

333. Fraser AG, McCarthy NJ, Evan GI. drICE is an essential caspase required for apoptotic activity in Drosophila cells. EMBO J 1997; 16: 6192-6199.

334. Song Z, McCall K, Steller H. DCP-1, a Drosophila cell death protease essential for development. Science 1997; 275: 536-540.

335. Yuan J, Shaham S, Ledoux S, Ellis HM, Horvitz HR. The C. elegans cell death gene ced-3 encodes a protein similar to mammalian interleukin-1 beta-converting enzyme. Cell 1993; 75: 641-652.

336. Fan TJ, Han LH, Cong RS, Liang J. Caspase family proteases and apoptosis. Acta Biochim Biophys Sin (Shanghai) 2005; 37: 719-727.

337. Martin SJ, Henry CM, Cullen SP. A perspective on mammalian caspases as positive and negative regulators of inflammation. Mol Cell 2012; 46: 387-397.

(c) (i) This work is licensed under a Creative Commons Attribution 3.0 Unported License. The images or other third party material in this article are included in the article's Creative Commons license, unless indicated otherwise in the credit line; if the material is not included under the Creative Commons license, users will need to obtain permission from the license holder to reproduce the material. To view a copy of this license, visit http://creativecommons. org/licenses/by/3.0/ 